\title{
Crowdseeding in Eastern Congo: Using Cell Phones to Collect Conflict Events Data in Real Time
}

\author{
Peter van der Windt* Macartan Humphreys
}

14 August 2014

\begin{abstract}
Poor quality data about conflict events can hinder humanitarian responses and bias academic research. There is increasing recognition of the role that new information technologies can play in producing more reliable data faster. We piloted a novel datagathering system in the Democratic Republic of Congo in which villagers in a set of randomly selected communities report on events in real time via SMS. We first describe the data and assess its reliability. We then examine the usefulness of such "crowdseeded" data in two ways. First, we implement a downstream experiment on aid and conflict and find evidence that aid can lead to fewer conflict events. Second, we examine conflict diffusion in Eastern Congo and find evidence that key dynamics operate at very micro levels. Both applications highlight the benefit of collecting conflict data via cell phones in real time.
\end{abstract}

*Paper published in Journal of Conflict Resolution: 2016, 60(4), 748-781. Corresponding author: petervanderwindt@nyu.edu. We would like to thank Junior Bulabula, Ruth Carlitz, Simon Collard-Wexler, Yair Ghitza, Stefan Lehmeier, Steven Livingston, Neelanjan Sircar, Patrick Meier and Lauren Young. We also thank Tracy Longacre, Desire Cimerhe and Alain Kabeya for outstanding in-country work. Voix des Kivus has been presented at a number of occasions: International Conference for Conflict Mapping, UNOCHA's Coordination Meeting, Folke Bernadotte Conference, World Bank Workshop (Bukavu), Free University Berlin, MPSA, the University of British Columbia, ISA, and Bristol University. We thank the participants at these meetings. The Voix des Kivus pilot project was funded by USAID and benefited from support from the group's learning network; we thank especially Borany Penh and John Berry. Thanks too to the IRC for their partnership on the larger study of the development interventions in Congo. Peter also thanks Wageningen University where part of this paper was written. Most of all we thank our 54 reporters who, by sending thousands of SMS-messages, made it possible to learn about events that take place in Eastern Congo. 


\section{Introduction}

Information technology is becoming increasingly visible as a means for gathering data on social trends. Web-based social networks are used to organize, mobilize and coordinate activities - from riots in London to regime change in the Middle East. Satellite imagery is used by the UNHCR to track population movements during conflicts or droughts, and by the ICC to learn about the presence of mass graves in Bosnia. And cell phones, combined with geo-mapping software, are used to create early-warning systems. Information technology is now also employed prominently in research. Satellite imagery has been used to study economic growth (Henderson et al., 2011, 2012), Twitter to learn about the Gaza Conflict (Zeitzoff, 2011), and GIS data to assess many elements of conflict (Lujala, 2010, Raleigh and Hegre, 2009; Lujala et al., 2005; Weidmann et al., 2010; Raleigh et al., 2010).

Despite broad interest in understanding patterns of political violence, the development of micro-level measures remains weak. There have been improvements in data collection on violence but this data is typically at a high level of aggregation. As Verwimp et al. (2009) argue: "At a fundamental level, conflict originates from individuals' behavior and their repeated interactions with their surroundings, in other words, from its micro-foundations" (p.307). Recent work by Autesserre in the Democratic Republic of Congo (DRC) illustrates the point: although the war officially came to an end in 2003, thousands of civilians still die each week. A plausible reason is that international interventions have focused at the regional and national levels; ignoring the local level where conflicts over land and political power became self-sustaining and autonomous from the national and regional tracks.1 1

Micro-level conflict data is normally collected by conducting surveys or interviews. However, obtaining such data in real time using traditional approaches is difficult because conflict events cluster in areas that have three characteristics. First, they are insecure, which limits the ability of researchers to visit them. Second, they are often physically hard to access (indeed difficult terrain is significantly related to a higher incidence of civil war (Fearon and Laitin, 2003)). Third, they may exhibit high levels of societal suspicion and distrust due to, for example, recent conflict experiences or the influx of new, unknown people due to displacement. These characteristics can create different types of biases that affect data quality.

First are selection biases. If areas are off-limits while conflict events take place, researchers often access and enlist the cooperation of only a (non-random) fraction of the research populations 2 Such selection biases may arise in subtle ways - for example, even if all areas are covered by a survey, security considerations may result in scheduling adjustments so that different regions are only visited when it is safe to do so. Also, testimonies are only taken from the living.

Second are risks of recall bias arising when data is gathered after the conclusion of

$\sqrt[1]{\text { Autesserre (2009) and Autesserre (2010). }}$.

2 Cohen and Arieli (2011) discuss how the populations in conflict areas are hidden from and hard to reach for researchers, and argue how the "snowball surveying" method works to access such populations. 
conflict. Coughlin (1990) provides an overview of the literature. While time cues might lessen this bias in some cases, De Nicola and Giné (2014) find evidence that the use of time cues can sometimes exacerbate the problem. One example is the problem of "telescoping" where respondents run together several events and lose track of when they actually happened. The importance of prompt data collection then may depend on the duration of the conflict and the number of events taking place.

Third are risks of reporting bias that may arise when sensitive questions are asked in settings characterized by distrust and suspicion. Trust has to be created to obtain highquality responses. However, this is especially difficult in conflict areas where data-collection is a one-off activity ${ }^{3}$ And of course, reporting may also be biased because of deliberate attempts to manipulate information $4^{4}$

We seek to investigate how information technology can overcome the problems associated with the collection of conflict data. To do so we piloted a "crowdseeding" system that collected information via SMS from pre-identified informants in randomly sampled locations. The project, Voix des Kivus, was implemented between 2009 and 2011 in the war-torn province of South Kivu in Eastern Democratic Republic of Congo. Large parts of the province are hard to access and although there is reasonable cell phone coverage, access to cell phone technology is limited.

In using cell phone technology we build off the "crowdsourcing" approach pioneered by groups such as Ushahidi. Under crowdsourcing, anyone can send an SMS-message to a central platform in which messages are gathered, stored and visualized on a map. Though clearly a compelling system for "fire alarm" monitoring, there are reasons to worry that the data generated through such systems is not representative. ${ }^{5}$ Reporters might send incorrect information - for example, they might over-report hardship hoping for humanitarian intervention. The data may also be unrepresentative for more innocent reasons: only people with access to a cell phone (and who have heard about the project) can send messages. Furthermore, the system will only receive messages from people who are willing to pay the cost of an SMS ${ }^{6}$

The crowdseeding approach seeks to combine the strengths of crowdsourcing technologies to generate detailed real-time data, with the strengths of traditional approaches that rely on known sources and representative samples. Like crowdsourcing, crowdseeding can

\footnotetext{
${ }^{3}$ Various approaches to get at sensitive information in these environments have recently been developed. See for example Corstange (2008).

${ }^{4}$ Luyendijk (2009), for example, discusses how in the Middle East the actors provide neatly packaged story lines to media reporters. A more subtle way to influence the data is for government or rebel groups to grant a researcher access to only certain areas, and deny it to others.

5 Berinsky et al. (2012), for example, find that information collected via Amazon's Mechanical Turk-a particularly popular crowdsourcing system to collect data for experimental research in political science-is not representative of the wider population.

${ }^{6} \mathrm{~A}$ Ushahidi-based crowdsourcing platform was introduced in Congo in 2008 to provide a platform to report on conflict events. The system fell out of use with only a handful of messages being received, despite many ongoing events, thus illustrating the risks of a system that depends on possibly weak supply incentives.
} 
alleviate some of the concerns regarding selection biases highlighted above. Rather than relying on discrete retrospective data gathering, these approaches rely on continuous information flows from individuals in the conflict region. Indeed even if an area is off-limits to a research team, SMS can still be sent and received. Moreover, real-time data gathering removes concerns related to recall. Crowdseeding offers additional advantages relative to crowdsourcing. First, by working with a random set of villages, data from a crowdseeding system renders data that is representative at the village level. Moreover, if the reporters are pre-identified and given the means to provide information, the risk that bias will be introduced when reporters self-select into the system is reduced. Even in the event of forced displacements, the reporter can continue providing information. Finally, crowdseeding may alleviate concerns associated with distrust because, by working with preselected reporters over extended periods, the system allows both for the generation of trust and for a greater ability to verify received information. Repeated interactions can reduce the incentive for reporters to send incorrect information and allows for ready auditing and verification of data.

In this paper we introduce data from the Voix des Kivus system and explore its utility in practice. In Section 2 we describe the implementation and feasibility of the system. We then present the data in Section 3, describing the distribution of messages, and assessing the overall data quality. Specifically, to assess data quality we investigate whether time, reporter type, and event type affect whether an event is reported, and compare the coverage to two existing conflict datasets collected by traditional survey methods and by ACLED's primarily media-based system. Section 4 provides two illustrations of the use of the data. In Section 4.1 we assess the effects of a downstream experiment on aid and conflict, exploiting additional data on the presence of a randomized development intervention in the region. Despite the small sample, we find evidence for a negative relationship between aid and conflict in this set of villages. In Section 4.2 we use the data to assess the spatio-temporal distribution of violence events. Though identification is weaker for this analysis, the evidence is consistent with large local spillover effects that decay at distances of around $50 \mathrm{~km}$. Both applications suggest that the assessments are highly sensitive to the timing of measurement in a way that often cannot be assessed from traditional conflict data sources. We conclude in Section 5 by considering ethical and practical implications of scaling up this type of data system.

\section{The Voix des Kivus System}

The Voix des Kivus (literally "Voice of the Kivus") data collection system was piloted in the province of South Kivu in the war-torn East of the Democratic Republic of Congo over an 18-month period starting in August 2009. The pilot ran in eighteen villages spread over four territories: Kalehe (5), Mwenga (4), Uvira (3), and Walungu (6) 7 Villages 1-4

\footnotetext{
${ }^{7}$ The territory is the administrative unit below the province and above the chiefdom.
} 
were selected purposely to ensure some conflict and some non-conflict areas; villages 5-18 were selected using stratified random sampling from these territories. Specifically, villages were randomly selected stratified by chiefdom and by the village's treatment status in a large development project (we will discuss the project in more detail in Section 4.1), taking village population sizes into account 8 Figure 1 shows the approximate area of operation 9 The headquarters of Voix des Kivus was Bukavu - the capital city of South Kivu and also the city where most of the province's NGOs are located.

Within these villages the Voix des Kivus system worked as follows. In each village we identified three reporters: one representing the traditional leadership (the chief of the village or his appointee), one representing women's groups (the head of the women's association or her appointee), and one elected by the community ${ }^{10}$

Reporters were given a phone and trained on how to send messages to the system. They were provided with a codesheet that lists possible events that can take place in the village, organized in ten categories: (1) presence of military forces, (2) attacks on the village, (3) deaths related to armed combat, (4) local violence and property loss, (5) displacement, (6) health events, (7) natural disasters, (8) development and NGO activities, (9) social events and (10) special codes. An overview of these codes is given in Table $1{ }^{11}$ Users could send a simple message containing one of these codes or they could send a standard "full text" message giving more particulars.

Reporters automatically received weekly phone credit that they could use freely, and were reimbursed for the number of messages sent. Remaining in the system required sending at least one message a week but this message could be blank. Thus sending messages to the system was free but it was also voluntary - while users did not have to pay for each message, they did not get any marginal financial rewards for sending content either. On the receiving side was a standard cell phone linked to a laptop computer. With freely available software (FrontlineSMS and R), messages received were automatically filtered, coded for content, cleaned to remove duplicates, and merged into a database. Graphs and tables were generated automatically and then mounted into bulletins with different levels of source identifiability. Translations of non-coded text messages (often from Swahili or

\footnotetext{
${ }^{8}$ The sampling frame and the code used to select the villages is available upon request.

${ }^{9}$ Note that to safeguard the safety of the reporters the village names are omitted. Moreover, locations within chiefdoms have been scrambled and so the actual location of participating villages can not be inferred from the location of points on this map. We provided information about village location only to pre-cleared organizations. We thank UNOCHA for the shapefiles used to construct this map.

${ }^{10}$ The idea behind these three reporters is that the chief is the go-to person for many affairs in a village ranging from land conflict to marital disputes. The head of the women's association, on the other hand, is often the go-to person for issues such as domestic violence. Finally one person is elected to decrease concerns of capture. These reporters can also be selected randomly to obtain a representative sample within the village.

${ }^{11}$ All documents can be found on the project's website: www.cu-csds.org/projects/event-mapping-incongo/. This also includes the computer code to create bulletins and a "Voix des Kivus Implementation Guide" for organizations that want to set up a similar system.
} 


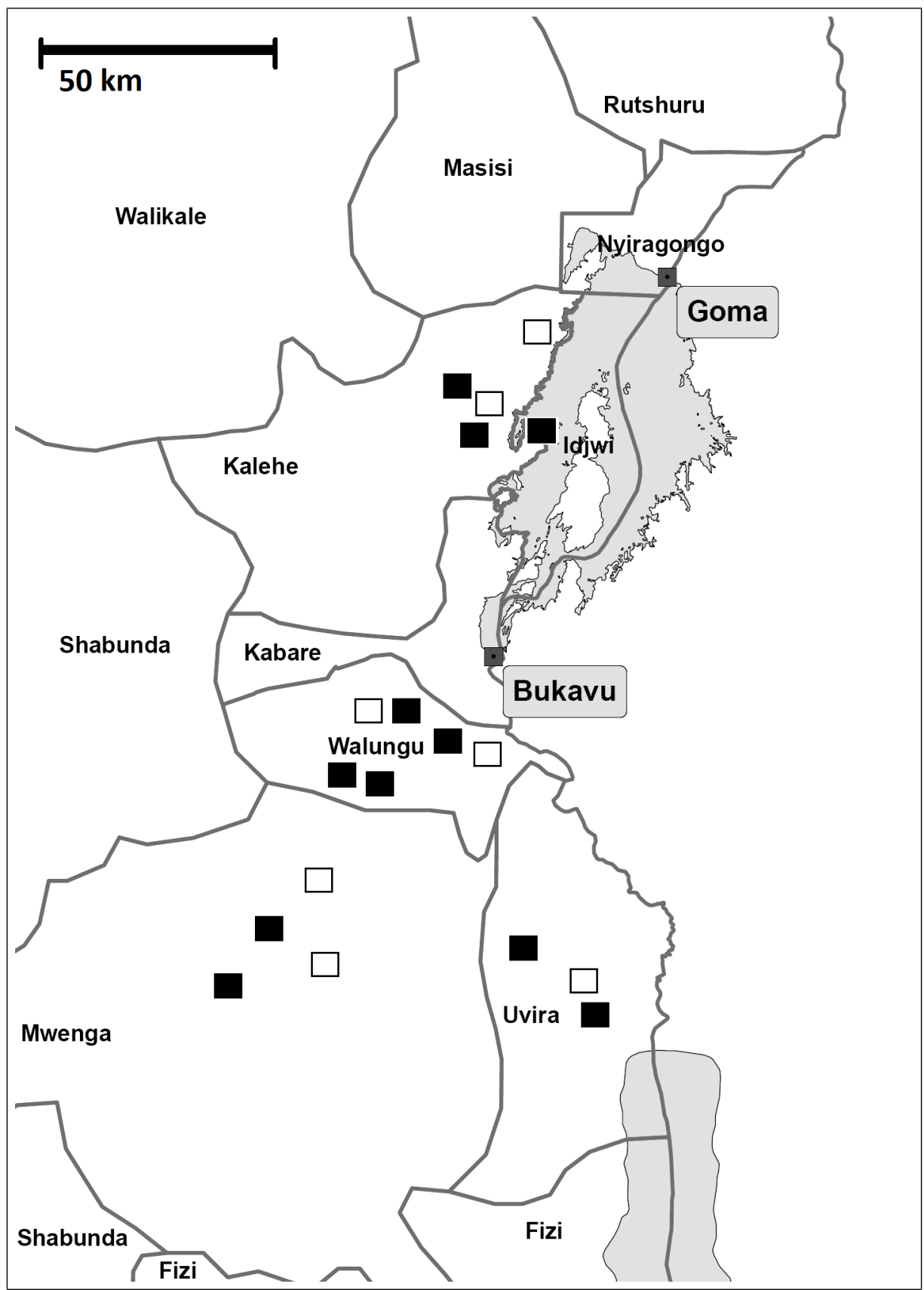

Figure 1: Map illustrating general area of Voix des Kivus operation. Squares denote approximate location of Voix des Kivus villages, accurate only up to the level of the chiefdom. Solid (hollow) squares denote villages that do (do not) participate in the development project discussed in Section 4.1. 
one of the local languages into French and English) were undertaken manually ${ }^{12}$

Our first goal in implementing the pilot was to assess the feasibility of data collection of this form. Establishing feasibility was important in light of a number of obvious challenges.

A first concern was that human capacity would be too weak for users to implement the project. Indeed, 19 of our 54 reporters had only primary level education and only two had received education beyond secondary school. This concern is likely to be present in many hard-to-access areas where conflict takes place. We mitigated this concern through a (minimum) two-day training by the field coordinator and the use of relatively simple code books with pre-coded events. In fact, over the eighteen months of operation Voix des Kivus received - in addition to SMS-messages with codes-1,144 text-messages in Swahili or one of the local languages; this suggests that the code book, while useful, was not necessary for many reporters.

A second concern was technical capacity. On the receiving side a cheap netbook, a phone and free software was sufficient. However, things were different on the sending side. Phone coverage was not a problem - of the eighteen villages no village had to be replaced after selection due to lack of coverage. Electricity, however, was a problem with reporters sometimes walking up to three hours to charge their phone. The problem was solved by purchasing $\$ 25$ solar chargers and donating one to each Voix des Kivus village. Providing consistent access to electricity through these low-cost solar chargers was important in ensuring regular information from the villages in our sample.

A third concern, however, is specific to crowdseeding systems: would participation in the system produce security risks for reporters? Over the course of eighteen months Voix des Kivus received thousands of messages, many of which were sensitive, including information on various types of abuses perpetrated by different actors. Because of the close connection between individual reporters and the project, we were concerned that there could be reprisals against reporters for sharing information. Beyond regular monitoring we used three strategies to address this concern. First, we operated in just four villages at first and subsequent villages were added only after one year of careful monitoring. Second, the weekly bulletins were generated in two versions. One version contained sensitive information (with village identifiers), the other did not. The sensitive bulletins were only disseminated to a very restricted set of organizations. Public versions contained no village identifiers. Third, the system allowed reporters to include a code (1-4) to a message to indicate the event's level of sensitivity, and with whom the information was to be shared (" 4 " only with Voix des Kivus, "3" also with close partners, "2" also with MONUSCO, and "1" everybody) ${ }^{13}$ We found that at no point did any user indicate any security concern of any

\footnotetext{
${ }^{12}$ While Voix des Kivus started as an academic exercise, such a system also has the potential to empower participating communities, and provide a basis for response to practitioners and policy advocates (Van der Windt (2013)). As a result, we set up a system in which each Monday a bulletin with event information was produced and disseminated to organizations that had received clearance from Voix des Kivus and its reporters. Many of these organizations are based in Bukavu and have the means to respond.

${ }^{13}$ From the introduction of these codes in August 2010 onwards the project received 3,214 event-messages.
} 
form arising from their participation in the project. However, although no concerns arose in our case, there are still general grounds for concerns for the security of the reporters in a crowdseeding system because of the direct link between reporters and the project. We return to this concern in the concluding section.

\section{The Data}

In this section we describe the data and assess data quality. Specifically, we explore reporting over time (is there evidence of fatigue?), reporting across monitors (do different reporters report differently?); are results robust to weights based on the number of reporters reporting the event?), and reporting by type of event (are conflict events more likely to be under-reported when the potential for sanctioning is higher?). Moreover, we compare the Voix des Kivus data to two existing conflict datasets collected by traditional survey methods and by ACLED's primarily media-based system.

Voix des Kivus was launched in August 2009 and operated during the first twelve months in only four villages. Then from August 2010 onwards the pilot project was expanded to eighteen villages. The expansion over time is illustrated in the top left panel of Figure $2{ }^{14}$ The regular system continued through to January 2011 (Figure 2 with a vertical line) but remained open for users to send messages - though without incentives for reporters - through to July 2011 15

The top right panel of Figure 2 shows the distribution of total event reports (dashed line) and conflict event reports (solid line) over time, per village. Overall the system generated a relatively constant stream of messages over this period. As shown in the lower left panel of Figure 2, reporters exhibited relatively little fatigue - while different reporters reported at different rates, they nevertheless reported at relatively constant rates over time 16

A total of 1,468 had a code that indicated the sensitivity of the message. Reporters were willing to distribute the data widely, with 1,092 messages (or $74 \%$ of those messages that included a code) being designated for distribution to "everybody." Codes 2, 3 and 4 were used, respectively, 108, 92 and 176 times. The majority of event-messages (1,751 or $54 \%$ of all event-messages), however, did not have a security code. Users suggested that this was not driven by a lack of understanding of the system, but by their preference to leave the decision of with whom to share what data with the project.

${ }^{14}$ Dates that Voix des Kivus started: 1-Aug-09 (3x), 17-Aug-09, 10-Aug-10, 13-Aug-10 (2x), 9-Oct-10 (2x), 26-Oct-10, 30-Oct-10, 1-Nov-10, 2-Nov-10 (2x), 4-Nov-10, 6-Dec-10, 8-Dec-10, 10-Dec-10. The village that started on 17-Aug-09 started later than expected because not enough people were present at the first general assembly. We had as rule that at least $40 \%$ of the village had to be present, be informed of the pilot project, and give their consent.

${ }^{15}$ In fact, in January 2011 we sent a one-time $\$ 20$ of phone credit to the reporters with the message that this phone credit was for them to use in any way they want, that they would still be reimbursed for their messages, and that we would continue to collect SMS messages and distribute the bulletins. However, we also told them that from that moment onwards they would no longer receive the weekly $\$ 1.5$ nor would they receive any feedback from the system. As can be seen from the top panel in Figure 2, the result was a gradual decline in the messages sent from January 2011 onwards reaching zero by July 2011.

${ }^{16}$ Reporting by one reporter (the upper-line) is anomalous. We noticed after one month that messages 

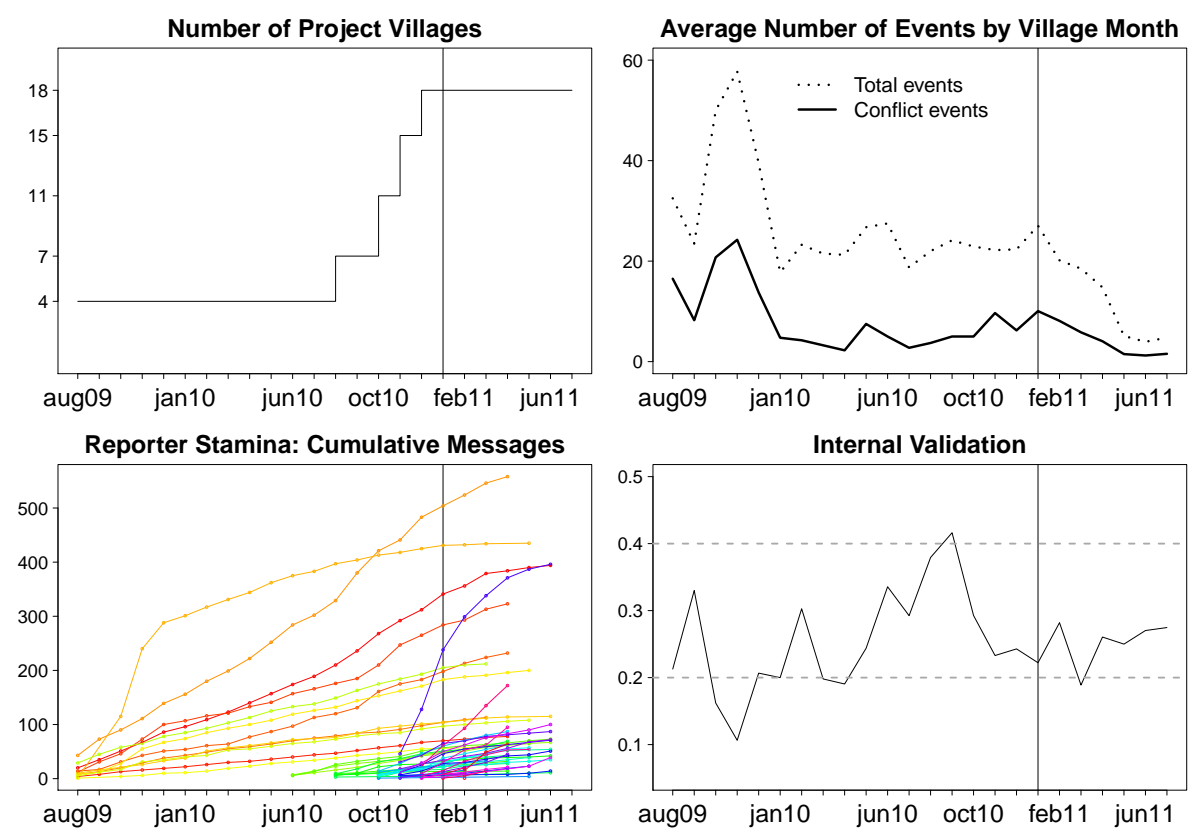

Figure 2: Top left panel shows the number of villages enrolled in the system over time; top right panel shows the average number of events per month by event type. Lower left panel shows reporter stamina - the cumulative number of events sent per reporter; this panel also indicates when reporters started and stopped sending messages. The lower right panel shows the level of "Internal Validation" - that is the share of messages sent that reported on events that were also reported by other reporters. 
In this short period the project received a total of 4,783 non-empty SMS messages. The reporters sent messages about a total of 5,081 events of which 4,623 were uniquemany village events were thus reported by more than one reporter. Of these non-empty SMS messages 1,144 were text-messages ${ }^{17}$ Table 1 provides summary information per event (where the unit of analysis is the village-month). Identical messages received from the same reporter within 30 minutes of each other, and identical messages received from different representatives in the same village within 24 hours of each other, are treated as single events. The table also reports the total number of messages sent per event. We find a large number of messages reporting the presence of troops (685). The most common conflict events include looting (233), violence between villagers (167) and kidnappings (135) - which in many cases involved forcing villagers to transport loads. We also find frequent reports of conflict-related deaths (292). Reports of sexual violence (99) indicate approximately equal numbers of men and women victims. Other major categories include outbreaks of diseases (277) and deaths due to disease (470), as well as crop failures (376).

Tables 2 and 3 show conditional correlations between these reported events. Specifically, each table shows the bivariate relationships between the column event and the row event as estimated by OLS. We control for village fixed effects to capture the correlation of different types of events within a village. Though we provide no causal interpretations, a number of patterns seen in Table 2 are worth highlighting. First, we see the the presence of troops is not itself a good predictor of conflict related deaths though it is strongly related to other types of violence (a category that includes looting and forced labor). Reports of attacks are associated with all other conflict and violent events, especially conflict deaths and displacement, but are only weakly associated with health events and social events. Adverse health events are not directly associated with attacks, but they are associated with displacement, disasters and local violence. General development actions are associated with almost all events; and social activities (such as visits and meetings) are associated with all events except attacks and conflict deaths. Overall, there is a clear clustering of bad things going together over time.

Table 3 focuses on the more disaggregated measures and reveals a number of striking correlations. First, presence by UN peacekeepers (MONUSCO) and government soldiers (FARDC) tends to be highly correlated. Second, we see that rebel group presence is associated with actions by MONUSCO and FARDC. Third, we see that presence in itself is generally not strongly associated with civilian deaths - the exception being the correlation between rebel presence and female deaths. Actions by FARDC are very strongly associated with deaths, particularly women's deaths. Actions by MONUSCO are not associated with deaths and actions by rebels or unidentified groups are only strongly associated with women's deaths.

by this reporter had been sent to the wrong phonenumber. The reporter had recorded his messages in a notebook however and subsequently uploaded them to the system (resulting in the steep slope in October 2009).

${ }^{17}$ This is based on the FrontlineSMS export of August 1, 2011. 


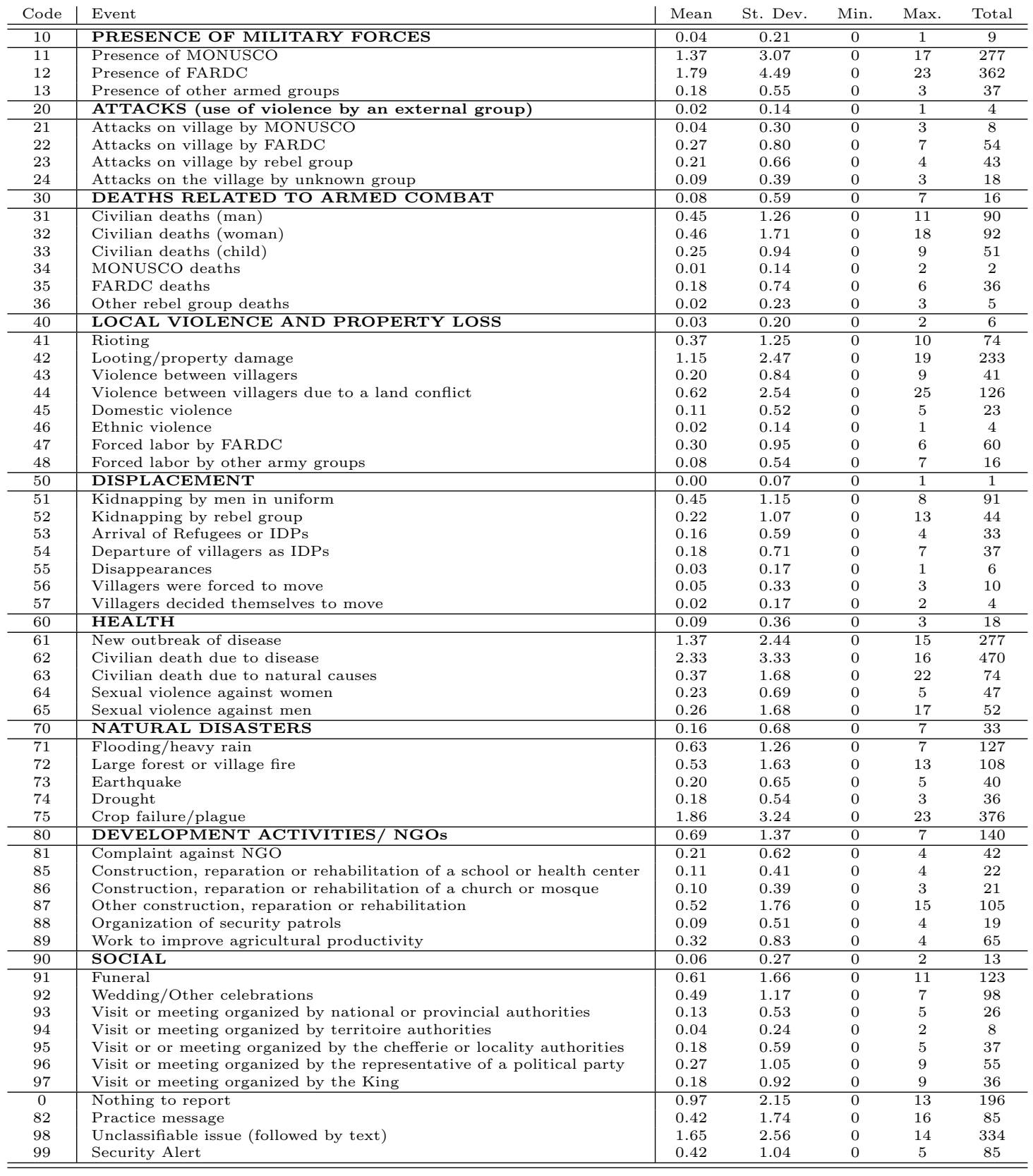

Table 1: Voix des Kivus Code book \& Summary Information. Mean, standard deviation, minimum and maximum are by village-month: i.e. a mean of 1.37 for code 11 indicates the number of times MONUSCO presence was reported during an average village-month. Based on a total of 202 observations. Events in the column "Total" add up to 5,081. When a text message could not be hand-coded to an event (e.g. "33"), it would be assigned to a category (e.g. "30"). Codes 84-89 and 91-97 were introduced only during the expansion in August 2010. Before the expansion codes 98 and 99 were 83 and 84, respectively. 


\begin{tabular}{|c|c|c|c|c|c|c|c|c|c|}
\hline & Presence & $\begin{array}{c}\text { Attacks/ } \\
\text { Actions }\end{array}$ & $\begin{array}{c}\text { Conflict } \\
\text { Deaths }\end{array}$ & $\begin{array}{c}\text { Local } \\
\text { Violence }\end{array}$ & $\begin{array}{c}\text { Displace- } \\
\text { ment }\end{array}$ & Health & Disasters & $\begin{array}{c}\text { Develop- } \\
\text { ment }\end{array}$ & Social \\
\hline Presence & & $\begin{array}{c}0.20 \\
(0.45)\end{array}$ & $\begin{array}{c}0.04 \\
(0.61)\end{array}$ & $\begin{array}{c}0.17 \\
(0.00)\end{array}$ & $\begin{array}{c}0.22 \\
(0.16)\end{array}$ & $\begin{array}{c}0.45 \\
(0.00)\end{array}$ & $\begin{array}{c}0.17 \\
(0.12)\end{array}$ & $\begin{array}{c}0.29 \\
(0.04)\end{array}$ & $\begin{array}{c}0.31 \\
(0.04)\end{array}$ \\
\hline Attacks & $\begin{array}{c}0.03 \\
(0.45)\end{array}$ & & $\begin{array}{c}0.16 \\
(0.00)\end{array}$ & $\begin{array}{c}0.07 \\
(0.00)\end{array}$ & $\begin{array}{c}0.15 \\
(0.01)\end{array}$ & $\begin{array}{c}0.04 \\
(0.23)\end{array}$ & $\begin{array}{c}0.10 \\
(0.01)\end{array}$ & $\begin{array}{c}0.25 \\
(0.00)\end{array}$ & $\begin{array}{c}0.04 \\
(0.41)\end{array}$ \\
\hline Conflict Deaths & $\begin{array}{c}0.06 \\
(0.61)\end{array}$ & $\begin{array}{l}1.99 \\
(0.00)\end{array}$ & & $\begin{array}{c}0.20 \\
(0.00)\end{array}$ & $\begin{array}{c}0.43 \\
(0.03)\end{array}$ & $\begin{array}{c}0.05 \\
(0.70)\end{array}$ & $\begin{array}{c}0.24 \\
(0.09)\end{array}$ & $\begin{array}{c}0.86 \\
(0.00)\end{array}$ & $\begin{array}{l}-0.09 \\
(0.62)\end{array}$ \\
\hline Local Violence & $\begin{array}{c}0.74 \\
(0.00)\end{array}$ & $\begin{array}{c}2.43 \\
(0.00)\end{array}$ & $\begin{array}{c}0.53 \\
(0.00)\end{array}$ & & $\begin{array}{c}1.26 \\
(0.00)\end{array}$ & $\begin{array}{c}0.66 \\
(0.00)\end{array}$ & $\begin{array}{c}1.82 \\
(0.00)\end{array}$ & $\begin{array}{c}1.82 \\
(0.00)\end{array}$ & $\begin{array}{c}1.61 \\
(0.00)\end{array}$ \\
\hline Displacement & $\begin{array}{c}0.08 \\
(0.16)\end{array}$ & $\begin{array}{c}0.43 \\
(0.01)\end{array}$ & $\begin{array}{c}0.10 \\
(0.03)\end{array}$ & $\begin{array}{c}0.11 \\
(0.00)\end{array}$ & & $\begin{array}{c}0.24 \\
(0.00)\end{array}$ & $\begin{array}{c}0.12 \\
(0.07)\end{array}$ & $\begin{array}{c}0.49 \\
(0.00)\end{array}$ & $\begin{array}{c}0.21 \\
(0.02)\end{array}$ \\
\hline Health & $\begin{array}{c}0.44 \\
(0.00)\end{array}$ & $\begin{array}{c}0.31 \\
(0.23)\end{array}$ & $\begin{array}{l}0.03 \\
(0.7)\end{array}$ & $\begin{array}{c}0.14 \\
(0.00)\end{array}$ & $\begin{array}{c}0.63 \\
(0.00)\end{array}$ & & $\begin{array}{c}0.21 \\
(0.05)\end{array}$ & $\begin{array}{c}0.27 \\
(0.05)\end{array}$ & $\begin{array}{c}0.48 \\
(0.00)\end{array}$ \\
\hline Disasters & $\begin{array}{c}0.13 \\
(0.12)\end{array}$ & $\begin{array}{c}0.58 \\
(0.01)\end{array}$ & $\begin{array}{c}0.11 \\
(0.09)\end{array}$ & $\begin{array}{c}0.32 \\
(0.00)\end{array}$ & $\begin{array}{c}0.25 \\
(0.07)\end{array}$ & $\begin{array}{c}0.17 \\
(0.05)\end{array}$ & & $\begin{array}{c}0.42 \\
(0.00)\end{array}$ & $\begin{array}{c}0.38 \\
(0.00)\end{array}$ \\
\hline Development & $\begin{array}{c}0.13 \\
(0.04)\end{array}$ & $\begin{array}{c}0.89 \\
(0.00)\end{array}$ & $\begin{array}{c}0.24 \\
(0.00)\end{array}$ & $\begin{array}{c}0.19 \\
(0.00)\end{array}$ & $\begin{array}{c}0.61 \\
(0.00)\end{array}$ & $\begin{array}{c}0.13 \\
(0.05)\end{array}$ & $\begin{array}{c}0.25 \\
(0.00)\end{array}$ & & $\begin{array}{c}0.24 \\
(0.02)\end{array}$ \\
\hline Social & $\begin{array}{c}0.13 \\
(0.04) \\
\end{array}$ & $\begin{array}{c}0.14 \\
(0.41) \\
\end{array}$ & $\begin{array}{c}-0.02 \\
(0.62) \\
\end{array}$ & $\begin{array}{c}0.15 \\
(0.00) \\
\end{array}$ & $\begin{array}{c}0.23 \\
(0.02) \\
\end{array}$ & $\begin{array}{c}0.20 \\
(0.00) \\
\end{array}$ & $\begin{array}{c}0.20 \\
(0.00)\end{array}$ & $\begin{array}{c}0.21 \\
(0.02) \\
\end{array}$ & \\
\hline
\end{tabular}

Table 2: Correlations between families of events reported by the Voix des Kivus pilot. Unit is the village-month; numbers are estimated "marginal effects" of column reports on row reports given village fixed effect; $p$ values in parentheses. Data from month 16 to end of period. To simplify comparisons the "Development" category in this table excludes patrols (88) and complaints (81); the social category excludes funerals (91). Sexual violence (64 and 65) are classed under "Local Violence", rather than "Health."

\begin{tabular}{|c|c|c|c|c|c|c|c|c|c|}
\hline & $\begin{array}{c}\text { MONUSCO } \\
\text { Present }\end{array}$ & $\begin{array}{l}\text { FARDC } \\
\text { Present }\end{array}$ & $\begin{array}{c}\text { Rebels } \\
\text { Present }\end{array}$ & $\begin{array}{c}\text { MONUSCO } \\
\text { Actions }\end{array}$ & $\begin{array}{l}\text { FARDC } \\
\text { Actions }\end{array}$ & $\begin{array}{c}\text { Rebel } \\
\text { Actions }\end{array}$ & $\begin{array}{c}\text { Male } \\
\text { Deaths }\end{array}$ & $\begin{array}{l}\text { Female } \\
\text { Deaths }\end{array}$ & $\begin{array}{l}\text { Child } \\
\text { Deaths }\end{array}$ \\
\hline MONUSCO Present & & $\begin{array}{c}0.58 \\
(0.00)\end{array}$ & $\begin{array}{c}0.24 \\
(0.52)\end{array}$ & $\begin{array}{c}0.43 \\
(0.62)\end{array}$ & $\begin{array}{c}0.06 \\
(0.76)\end{array}$ & $\begin{array}{l}-0.03 \\
(0.87)\end{array}$ & $\begin{array}{c}0.07 \\
(0.58)\end{array}$ & $\begin{array}{c}0.09 \\
(0.32)\end{array}$ & $\begin{array}{c}0.08 \\
(0.62)\end{array}$ \\
\hline FARDC Present & $\begin{array}{c}0.78 \\
(0.00)\end{array}$ & & $\begin{array}{c}0.08 \\
(0.86)\end{array}$ & $\begin{array}{l}-0.57 \\
(0.56)\end{array}$ & $\begin{array}{c}0.04 \\
(0.88)\end{array}$ & $\begin{array}{c}0.20 \\
(0.43)\end{array}$ & $\begin{array}{c}0.00 \\
(1.00)\end{array}$ & $\begin{array}{c}0.02 \\
(0.88)\end{array}$ & $\begin{array}{l}-0.06 \\
(0.75)\end{array}$ \\
\hline Rebels Present & $\begin{array}{c}0.02 \\
(0.52)\end{array}$ & $\begin{array}{c}0.00 \\
(0.86)\end{array}$ & & $\begin{array}{l}1.43 \\
(0.00)\end{array}$ & $\begin{array}{c}0.17 \\
(0.00)\end{array}$ & $\begin{array}{l}-0.02 \\
(0.70)\end{array}$ & $\begin{array}{c}0.04 \\
(0.22)\end{array}$ & $\begin{array}{c}0.04 \\
(0.08)\end{array}$ & $\begin{array}{c}0.03 \\
(0.47)\end{array}$ \\
\hline MONUSCO Actions & $\begin{array}{c}0.01 \\
(0.62)\end{array}$ & $\begin{array}{l}-0.01 \\
(0.56)\end{array}$ & $\begin{array}{c}0.27 \\
(0.00)\end{array}$ & & $\begin{array}{c}0.03 \\
(0.16)\end{array}$ & $\begin{array}{l}-0.02 \\
(0.45)\end{array}$ & $\begin{array}{l}0.00 \\
(0.83)\end{array}$ & $\begin{array}{c}0.00 \\
(0.65)\end{array}$ & $\begin{array}{c}0.00 \\
(1.00)\end{array}$ \\
\hline FARDC Actions & $\begin{array}{c}0.01 \\
(0.76)\end{array}$ & $\begin{array}{c}0.01 \\
(0.88)\end{array}$ & $\begin{array}{c}0.61 \\
(0.00)\end{array}$ & $\begin{array}{c}0.57 \\
(0.16)\end{array}$ & & $\begin{array}{c}0.08 \\
(0.43)\end{array}$ & $\begin{array}{c}0.34 \\
(0.00)\end{array}$ & $\begin{array}{c}0.28 \\
(0.00)\end{array}$ & $\begin{array}{c}0.43 \\
(0.00)\end{array}$ \\
\hline Rebels Actions & $\begin{array}{l}-0.01 \\
(0.87)\end{array}$ & $\begin{array}{c}0.03 \\
(0.43)\end{array}$ & $\begin{array}{l}-0.06 \\
(0.70)\end{array}$ & $\begin{array}{l}-0.29 \\
(0.45)\end{array}$ & $\begin{array}{c}0.07 \\
(0.43)\end{array}$ & & $\begin{array}{l}0.09 \\
(0.11)\end{array}$ & $\begin{array}{c}0.07 \\
(0.08)\end{array}$ & $\begin{array}{c}0.10 \\
(0.16)\end{array}$ \\
\hline Male Death & $\begin{array}{c}0.04 \\
(0.58)\end{array}$ & $\begin{array}{c}0.00 \\
(1.00)\end{array}$ & $\begin{array}{c}0.35 \\
(0.22)\end{array}$ & $\begin{array}{c}0.14 \\
(0.83)\end{array}$ & $\begin{array}{c}0.91 \\
(0.00)\end{array}$ & $\begin{array}{c}0.27 \\
(0.11)\end{array}$ & & $\begin{array}{l}0.47 \\
(0.00)\end{array}$ & $\begin{array}{c}0.49 \\
(0.00)\end{array}$ \\
\hline Female Death & $\begin{array}{c}0.1 \\
(0.32)\end{array}$ & $\begin{array}{c}0.01 \\
(0.88)\end{array}$ & $\begin{array}{c}0.71 \\
(0.08)\end{array}$ & $\begin{array}{c}0.43 \\
(0.65)\end{array}$ & $\begin{array}{c}1.42 \\
(0.00)\end{array}$ & $\begin{array}{c}0.42 \\
(0.08)\end{array}$ & $\begin{array}{c}0.91 \\
(0.00)\end{array}$ & & $\begin{array}{c}1.34 \\
(0.00)\end{array}$ \\
\hline Child Death & $\begin{array}{c}0.03 \\
(0.62) \\
\end{array}$ & $\begin{array}{l}-0.02 \\
(0.75) \\
\end{array}$ & $\begin{array}{c}0.17 \\
(0.47) \\
\end{array}$ & $\begin{array}{c}0.00 \\
(1.00) \\
\end{array}$ & $\begin{array}{c}0.71 \\
(0.00) \\
\end{array}$ & $\begin{array}{c}0.19 \\
(0.16) \\
\end{array}$ & $\begin{array}{c}0.3 \\
(0.00) \\
\end{array}$ & $\begin{array}{c}0.43 \\
(0.00) \\
\end{array}$ & \\
\hline
\end{tabular}

Table 3: Correlations between conflict related events reported by the Voix des Kivus pilot. Unit is the village-month; numbers are estimated "marginal effects" of column reports on row reports given village fixed effect; $p$ values in parentheses. Data from month 16 to end of period.

\subsection{Data Quality}

Voix des Kivus was implemented to assess the feasibility of using crowdseeding to gather high-quality data. In the absence of a gold standard for conflict event data it is difficult 
to formally validate the approach employed here. Nevertheless five considerations on data quality are worth emphasizing.

First, in its first year Voix des Kivus employed a field coordinator to visit each of the reporters at least once every two weeks to assess the quality of the messages sent 18 The coordinator would assess whether reporters interpreted codes in the same way as the researchers, whether respondents employed the correct codes given the events they wished to report, and so on. Moreover, the field coordinator would verify whether events had actually taken place and whether there were other events that took place that were not reported. Throughout the pilot the coordinator found no instances of erroneous reports of major conflict events (incursions, assaults or killings) but did find numerous instances where events were not communicated by one or all reporters, suggesting a vulnerability to Type II errors.

Second, because Voix des Kivus distributed phones to three people per village we have a measure of internal validation. The bottom right panel of Figure 2 shows the share of events that were reported by at least two reporters out of all events reported. We find that internal validation was around $30 \%$ at the outset but increased after the project start until August 2010 - the moment the project expanded to more villages 19

Third, we have a limited ability to compare event information received from the Voix des Kivus system with that from data from a survey we implemented in the same region in a similar period. In the latter we asked each village chief, how many events from a list of potential events had taken place in the village in the preceding month. Our survey villages overlapped with just three Voix des Kivus villages during the lifespan of the project 20 We consider three ways of assessing the congruence of the survey and the Voix des Kivus data. First, we compare the average number of each type of event across villages under each approach. On average we find nearly twice as many reported events according to the survey. In particular, there were higher numbers of children's deaths due to conflict, citizen deaths due to natural causes, disease outbreaks, and funerals reported in the survey. Second, despite the difference in means, the correlation between these two measures of average incidence is $46 \%$ which is substantively large and statistically significant. This suggests that similar types of events get reported to the same relative extent under the two systems. Third, we generate measures of the average incidence of conflict and nonconflict events for

\footnotetext{
${ }^{18}$ To do so Voix des Kivus would prepare a sheet with the messages sent by that reporter in the preceding two weeks. For security reasons these were decoded in such a way that the information only made sense to our field coordinator.

${ }^{19}$ The improvements and subsequent decline in validation may in part result from our communications with reporters. Consulting reporters suggested that the low internal validation early on was in part due to reporters informally adopting a division of labor where one would not send a message if they knew another had. In the early months with the first villages we encouraged reporters not to do this and to report whether or not they thought others did also. This same messaging was not employed to the same extent with the later villages as they came online and we see a subsequent drop in the level of internal validation.

${ }^{20}$ And we note that even for these three the survey took place during the final 'voluntary' phase in which payments were no longer being made to reporters (see Section 3 ).
} 
each of the three villages using each of the two data sources, yielding 12 data points 21 The correlation between the Voix des Kivus and survey estimates is low largely because of one outlying observation in which a village reported a much higher incidence of army visits under the Voix des Kivus system. If this outlier is dropped the correlation between the Voix des Kivus and the survey based measure is $95 \%$. These correlations are encouraging although we note that survey measures are also subject to measurement error and bias, and so on their own the correlations do not establish the reliability of the data ${ }^{22}$

Fourth, a problem for any data-collection method in conflict areas, including surveys, is censorship. For example, informants might report fewer conflict events precisely because of the presence of armed groups and high levels of conflict. In practice our reporters provided detailed data on events even when troops were present or in the vicinity. Messages such as "FARDC passed by [Village Omitted] and shot with guns at 5:30 am" and "A FARDC soldier shot a woman" are not uncommon. And messages such as "FARDC kidnapped people who were then forced to transport things" and "FARDC kidnapped people to build a shelter for the soldiers" were received almost weekly by Voix des Kivus. In addition, we observe many instances in which there is simultaneous reporting of the presence of armed actors and adverse events of various kinds. Moreover, at no point did reporters indicate to us that they felt a need to censor reports.

Finally, we note a concern of uneven reporter participation. The total quantity of messages sent varies substantially across villages; from month 16 onwards, total reporting varies from a low of 14 from one village to a high of 522 for another. Alongside this broad variation is a positive correlation between reports of events of many types (as seen in Tables 2 and 3). These patterns may reflect true variation but they are also consistent with variation in the overall activity of reporters ${ }^{23}$ As we demonstrate in the next section we find mixed evidence on differential behavior by reporter type. Nevertheless, we believe that heterogeneity in propensities to report could be a fruitful focus of scrutiny in future applications.

\subsection{Source Dependence}

A crowdsourcing system receives information from an unidentified, anonymous public. A crowdseeding system, in contrast, makes use of identifiable users. The ability to analyze

\footnotetext{
${ }^{21}$ This yields data of the form: $\{1,34,9,10\},\{1,5,2,27\}$ and $\{0,9,7,33\}$, denoting respectively the number of conflict events and nonconflict events measured by Voix des Kivus and the number of conflict and nonconflict events measured by the survey, by village.

${ }^{22}$ We also note that in this case since the chief was also involved with Voix des Kivus the comparison of systems involves comparing reports from the same actor, which may give rise to concerns that the two reports would be more similar than they would be if recorded from different subjects.

${ }^{23}$ While positive correlations may be expected across many pairs of event types, we would expect a negative correlation at least for the incidence of flooding and of droughts. For this pair we do indeed find a negative correlation, though it is small in magnitude $(-0.02)$ and there are three village-months in which both events were reported.
} 
the "crowd" in more detail and learn whether particular types of reporters provide different information is a significant benefit.

In the case of Voix des Kivus, a reporter's position (chief, women's representative or elected individual) is a natural starting point to differentiate the crowd. We find that village chiefs sent substantially more messages than the women's representative or the elected reporter: respectively 11.62, 8.30 and 8.90 messages per person per month on average 24

Subdividing the data by conflict and non-conflict events we find that around $30 \%$ of the messages sent concern conflict events - with elected reporters sending relatively the most 25 Regressing the number of conflict events reported per month on the type of reporter and the number of non-conflict events reported in that month - with the chief as baseline and standard errors clustered at the village level-partially confirms this. We obtain estimates equal to 0.23 (0.63) and 1.49 (1.33) for the women's representative and the elected reporter respectively (standard errors in parentheses). These differences in messaging by reporterposition are not statistically significant however.

Reporters may nevertheless differ in the types of events they report. A major task of the chief is to settle disputes among villagers, particularly those over land. Another is to be the village's first point of contact for visitors such as migrants, government officials, etc. In contrast, the head of the women's association may be the go-to person for women that experience sexual violence or domestic violence. On the other hand, our three reporters are likely to be similarly aware of events such as funerals and weddings, and activities such as road repairs and construction of the school, because Congolese villages are small and these events are public. The table in the Appendix presents the average number of messages sent per village-month by reporter type, where we also tests the difference between them. On average, chiefs send more messages regarding land conflict (code 44) than women representatives, but fewer than elected reporters - only the first difference is slightly significant. Chiefs - compared to elected reporters - are statistically more likely to report the arrival of refugees and IDPs (53), and visits or meetings organized by the chiefdom or locality authorities (95) and by representative of a political party (96). We do not find that the women representatives report more domestic violence (45) or more sexual violence against women (64).

The crowd is not a random subset of the total population and in general what one learns likely depends on whom one asks. Overall, however, our analysis suggests that in this data at least, differences in reporting across the three categories of reporters in the Voix des Kivus villages is relatively muted.

\footnotetext{
${ }^{24}$ There is also a large variation over time for these three types of reporters, with standard deviations of respectively $14.10,7.54$, and 13.44 .

${ }^{25}$ The share of conflict events reported over total events reported is $0.28(0.30), 0.32(0.33), 0.34(0.33)$ respectively for the chief, the women's representative, and the elected reporter (standard deviation in parentheses). On average they sent respectively 2.81 (5.89), 2.14 (2.48), 3.11 (7.31) messages concerning conflict per month.
} 


\subsection{Relation with ACLED data}

We close our discussion of data quality with a comparison of data from the system and data from what we believe is the best available alternative: the Armed Conflict Location and Events (ACLED) dataset, which gathers together data on the specific dates and locations of conflict events, as well as ancillary information such as the types of event and the groups involved (Raleigh et al. (2010)) ${ }^{26}$ The dataset is global in reach, and for the DRC the dataset contains 6,926 conflict events since January 1, 1997.

Because conflict clusters in isolated areas, one benefit of a crowdseeding system is that it records conflict events that otherwise would have gone unnoticed. To test this idea we compare the number of conflict events reported to Voix des Kivus with the number of conflict events reported by ACLED for the same region and time period ${ }^{27}$ The ACLED database reports 27 conflict events divided over the following event types: battle with no change of territory control, battle with rebel control location, battle with government regaining territory, headquarters or base establishment, non-violent activity by a conflict actor, rioting/protesting, violence against civilians, and non-violent transfer of location control. During this same period Voix des Kivus, on the other hand, received a total of 1,439 conflict event messages, and this increases to 2,118 messages if events related to the presence of conflict actors is included 28 This difference in number of conflict events reported is particularly large considering that Voix des Kivus reports events for only 18 villages, while ACLED reports conflict events for the whole area.

Alongside these quantitative differences there may be qualitative differences reflecting, for example, the differences in the sources upon which these data are based. The ACLED dataset derives information from a variety of sources, which include news reports, humanitarian agencies, and research publications ${ }^{29}$ Voix des Kivus, on the other hand, relies on reporting by community-based reporters. To examine differences, we focus on measures of who perpetrates violence against civilians ${ }^{30}$ This is a sensitive topic and different reports might under- or over-report the importance of one actor or another. Both ACLED and Voix des Kivus separate out violence against civilians by perpetrator. The Voix des Kivus data indicates that FARDC is an important perpetrator of violence against civilians, being

\footnotetext{
${ }^{26}$ ACLED data can be download freely at: www.acleddata.com/data. The file used has been last updated on January 1. 2013.

${ }^{27}$ That is, the period August 1, 2009 to December 31, 2010, and South Kivu's territories of Kalehe, Walungu, Mwenga, and Uvira.

${ }^{28}$ The column "Total" in Table 1 presents this result disaggregated by event type.

${ }^{29}$ The 27 events were sourced from Africa Research Bulletin, AFP, All Africa, Associated Press Newswires, Associated Press Newswires, BBC, and Reuters.

${ }^{30}$ ACLED collects information on the dyad characteristics of conflict events subdividing the 27 events into: sole military action $(1 \times)$, military versus rebels $(8 \times)$, military versus political militia $(1 \times)$, military versus civilians $(2 \times)$, military versus other $(1 \times)$, sole rebel action $(2 \times)$, rebels versus political militia $(2 \times)$, rebels versus civilians $(5 \times)$, political militia versus civilians $(4 \times)$, political militia versus others $(1 \times)$. Violence against civilians corresponds closely to our definition of attack on the villages (codes 21-24). ACLED has a total of eleven such events, while Voix des Kivus has 103.
} 
responsible for almost $50 \%$ of the attacks against civilians. ACLED, on the other hand, indicates that most violence against civilians is perpetrated by rebel groups, and less than $20 \%$ of the violence is initiated by government soldiers 31 This number drops to $10 \%$ when analyzing the ACLED data for the whole period (totaling 239 attacks against civilians) 32 The two datasets thus paint a very different picture when it comes to who perpetrates conflict against civilians.

\section{Research Applications}

A system like Voix des Kivus provides rich data to learn about conflict areas. Relationships between different event types can be analyzed as we did in Section 3 . Particular use can be made of the data's panel-component to learn about the dynamics of different events over time 33 Another interesting application of a phone-based system is to combine it with external data-sources, and use the data collected by phone as an outcome measure. The local United Nations offices could provide historic information about patrol routes which can then be used to learn whether these patrols pacify a region or simply move violence by a rebel group from one area to another 34 The data could be combined with satellite information about weather patterns to learn about the impact of, for example, rainfall on different types and levels of conflict. To learn about election violence, data could be collected from Congo's National Election Committee on the location of voting booths (in November 2011 the presidential elections took place in Congo and was in some areas characterized by high levels of violence). Another possibility is to use a Voix des Kivus style system as a treatment in order to examine the effects of transparency on conflict outcomes of interest.

In this section we provide two applications, where Voix des Kivus data provides outcome data, to illustrate the utility of this kind of data for research. First, we try to assess the conflict impact of development aid. Second, we use the data to learn about the temporalspatial nature of conflict. In both cases we highlight ways in which the conclusions we draw might differ from conclusions that we might draw using more traditional approaches.

\footnotetext{
${ }^{31}$ Voix des Kivus: MONUSCO (8, 6\%), FARDC (58, 46\%), rebel (43, 34\%), unknown (18, 14\%). ACLED: MONUSCO (0, 0\%), FARDC (2, 18\%), rebel (6, 55\%), unknown (3, 27\%).

${ }^{32}$ Specifically, this is the period February, 12, 1997 to December, 12, 2012. The breakdown by perpetrator is as follows: FARDC $(25,10 \%)$, Rebel $(190,80 \%)$, unknown $(24,10 \%)$.

${ }^{33}$ See, for example, Zeitzoff (2011) who draws data on hourly conflict intensity from Twitter and other social media to learn about the Gaza Conflict (2008-2009).

${ }^{34}$ This is an important question that we should also ask in Section 4.1 where we analyze the conflict impact of a development program. Does this program decrease the level of violence, or is violence simply moved to another area? We do not answer this question in the paper. In Section 4.2 we do investigate the use of crowdseeding data to learn about conflict diffusion in more general.
} 


\subsection{Application 1: The Conflict Impact of Development Programs}

There is broad recognition that development and conflict are closely related. Major development interventions focus on countries emerging from war and include reintegration, reconstruction, capacity building and other initiatives. It remains unclear, however, if and how these investments are effective. It is expected that by improving the level of development, these projects could reduce risks of violence. Miguel et al. (2004), for example, find that economic growth is strongly negatively related to civil conflict. And De Ree and Nillesen (2009) argue that foreign aid is found to have a direct negative impact on the probability of an ongoing civil conflict to continue 35 On the other hand, the very introduction of development actors, financing, and projects could also increase violence. Nunn and Qian (2014), for example, suggest that U.S. food aid increases the incidence, onset and duration of civil conflicts in recipient countries and related arguments have been made by Anderson (1999), De Waal (2009), and Polman (2011). There are multiple reasons why these relations - or opposite relations - may obtain. These include changing the resource(s) available for looting, changing the capacity of local communities to respond, changing the incentives of local communities to participate in violence, and increasing the extent to which communities are - or are believed to be - monitored by external actors.

Much of this development-conflict literature is at the macro, often the national, level. Conflict research at the micro-level, and in particular the impact of development aid on local levels of violence, is sparse and what does exist has up to recently been largely of a descriptive nature ${ }^{36}$ This is not surprising because attempts to find out whether these aid programs actually have an impact on the level of violence face major identification and measurement challenges (for recent studies that seek to address the identification challenge at the micro level see Berman et al. (2011); Crost et al. (2012); Beath et al. (2011)).

This section shows how crowdseeded data can be coupled with a downstream experiment to address these problems at the micro level. Between 2007-2011 a DFID-funded randomized development intervention was implemented by the International Rescue Committee and CARE International throughout Eastern Congo -including the province of South Kivu. The villages were selected into the development program by a public lotterythus in expectation treatment and control villages are alike in all respects except for the intervention itself. The development project provided communities with financing of up to $\$ 70,000$ to construct local projects such as school rooms or clinics - part of this money was received and managed by the communities directly. The intervention followed a "do no harm" approach - that is, the projects were implemented in a way that sought to ensure that they did not spark local conflicts. During the selection of the Voix des Kivus villages we took account of the random assignment of this development intervention, stratifying our sample upon the villages' treatment status in order to obtain balance between the number

\footnotetext{
${ }^{35}$ See also Collier $(2003)$ and Bates $(2009)$.

${ }^{36}$ In addition, little work exists that ties both levels together. See for a particular strong illustration of the disconnect between the micro and macro levels in the DRC: Autesserre (2010).
} 
of Voix des Kivus villages that had the development program and those that did not.

Even with a small sample such as we have, random assignment ensures that simple difference in means provides an unbiased estimate of the treatment effect. Of course with a small sample our power is weak and we can expect our estimates to be somewhat noisy, though this does not threaten unbiasedness (e.g. Mutz and Pemantle (2011); Imai et al. (2008)).

The top line in Figure 3 s top left panel shows the estimated impact of development aid on the incidence of conflict using simple differences in means. The points are estimates calculated for each month, based upon village-month data for that month and the preceding two months. The gray area indicates the $95 \%$ confidence interval, where the standard errors are clustered at the village level. The bottom line shows the corresponding $p$-values 37 Conflict events are measured as the message-codes: 21-56, 64-65, and 99. Note that this construction separates the troop presence measures from the violent event measures. Two results stand out. First, we see that the magnitudes vary over time, with strong estimates of effects in early periods which then decline and reemerge, though never to initial levels. Second, the data provides evidence of a positive impact of development aid: that is, villages with the development program have a lower level of conflict incidence. Not only are the point estimates of the development impact consistently below the zero line, so are most of the $95 \%$ confidence intervals, which is reflected in the fact that the majority of estimated $p$-values $(13 / 22)$ are at or below 0.1 .

A set of robustness checks, presented in the other three panels in Figure 3, give further confidence in these results. First, we provide results using a randomization inference procedure (Fisher, 1935) ${ }^{38}$ We repeatedly randomly re-assigned our eighteen villages to the treatment and for each of these new re-assignments to treatment we calculated the distribution of possible estimated effect under the null of no effect. We then estimated how likely it is we would have obtained results as strong or stronger than we did under this null. These results are presented in the top right panel of Figure 3. using this approach we find $7 / 22$ of the estimated $p$-values at or below 0.1 , and $5 / 22$ below 0.05 . Note that in the early periods in which there are only 4 villages the $p$ values from randomization inference can never drop below 0.25 , correctly reflecting the severely restricted set of permutations that are possible with this small set of cases. In later periods, where it is technically possible to have lower $p$ values, these values drop to below standard thresholds.

In this figure we also include shorter, thin lines that are estimated when we restrict our analysis to exclude the first four purposefully selected villages that entered the system 39

\footnotetext{
${ }^{37}$ All $p$ values in the analyses in this sub-section are based upon two-tailed tests given the uncertain expectations over the direction of the average effects of aid.

${ }^{38}$ See also: Barrios et al. (2012), Small et al. (2008), and Ho and Imai (2006). The analyses take into account that not each village had the same probability to be selected into the Tuungane program.

${ }^{39}$ These lines start at November 2010 for two reasons. First, as the bottom panel of Figure 2 illustrates, Voix des Kivus' expansion was only gradually: three villages were added in August 2010, four during October 2010, etc. Second, the monthly estimates are based upon data from that month and the preceding
} 
Three Month: OLS

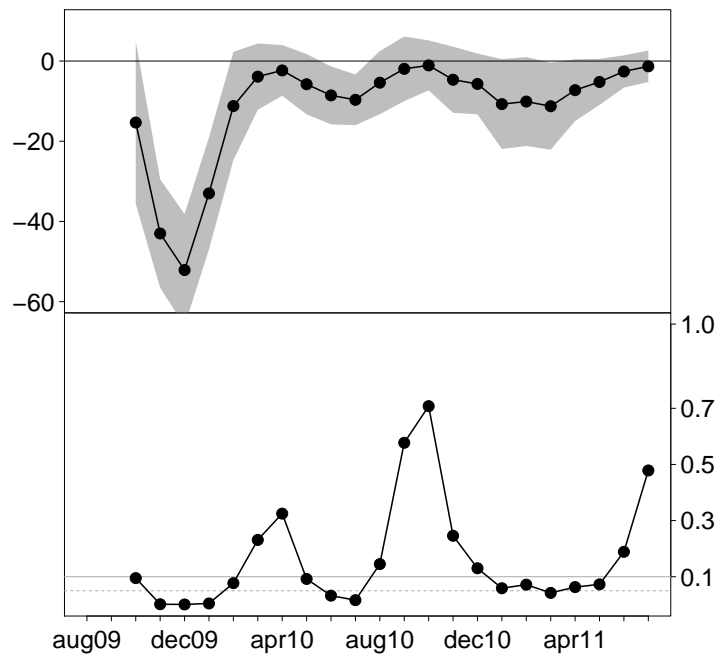

Internal Validation

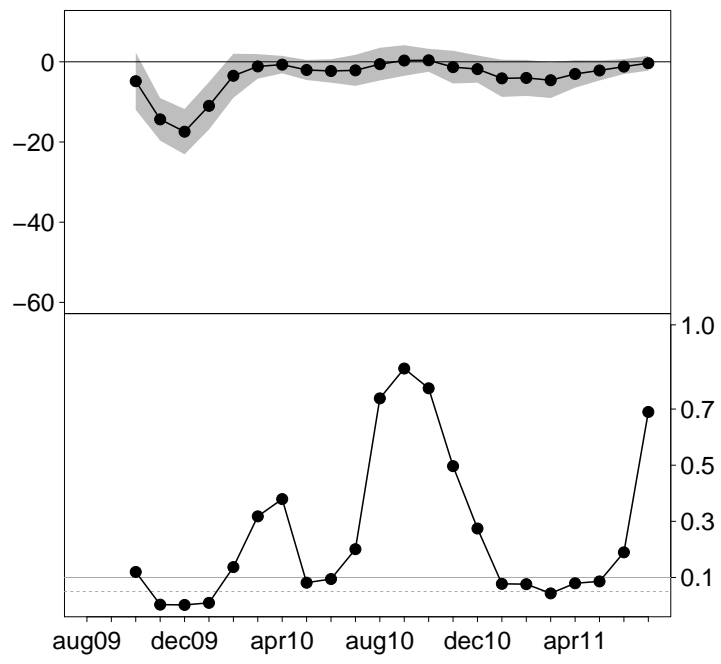

Three Month: RI

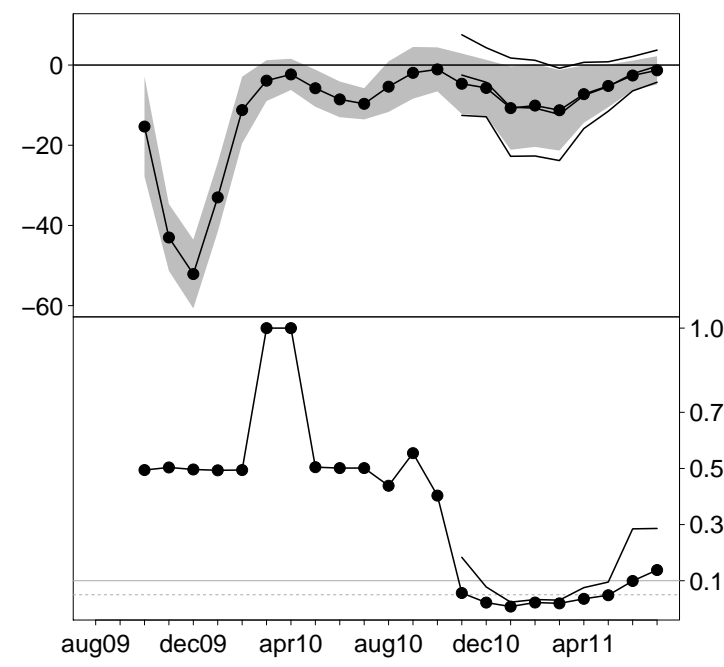

Cumulative: RI

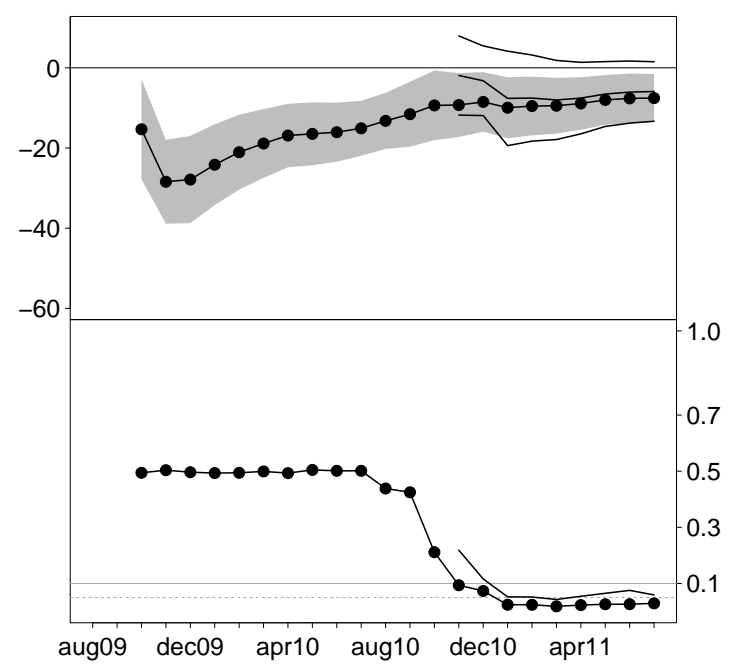

Figure 3: Conflict Impact of Development Aid. The top left panel shows estimated effects (top black line) based on data for that month and the preceding two months, including 95\% confidence intervals (gray area) and the corresponding $p$-values (bottom black line). The top right panel presents results of the randomization inference for the full sample and the restricted sample (short, thin lines). The restricted sample drops the initial four villages. The bottom left panel presents results where conflict events reported by one (two) individuals are weighted one-third (one-half) as much as those reports reported by three individuals. Based on accumulated data over time, the bottom right panel shows results of randomization inference for the full sample and the restricted sample. 
We find that excluding the first four Voix des Kivus villages makes little difference to our estimates. The estimates, confidence intervals and $p$-values are almost identical.

In a second robustness check we leverage the possibility for internal validation of crowdseeded data. Recall that each event can be reported by one, two or all three of our reporters. Because we are more confident that events reported by three individuals have taken place (or have been substantially important), we regard those conflict events reported by one (two) individuals one-third (one-half) as much as those events reported by three individuals. Results are presented in the bottom left panel in Figure 3 . The overall results are very similar to those from the main analysis although the magnitudes ( $p$ values) are generally somewhat lower (higher). Finally, the lower right panel of the figure shows comparable results for the cumulative effects; here again $p$ values fall as the sample expands; using the full sample the effects are strongest though this in part reflects the effects induced by the first set of villages. As shown by the thinner lines on the graph however the results are not very sensitive to dropping these units.

Figure 3 reports results for each month. Given this collection of findings can we conclude that the project led to less conflict overall? That is, while in most periods the estimates are negative and statistically significant, there are periods in which the estimate is not significantly different from zero. This gives rise to a multiple comparisons problem. We again use randomization inference to address this problem 40 Specifically, we repeatedly randomly re-assigned our eighteen villages to the treatment to generate a distribution of estimated effects for the entire period under the sharp null of no effect for any unit. ${ }^{41} \mathrm{We}$ then assess how likely it is that we would have obtained results as strong or stronger than we did. We calculate a $p$-value of 0.02 for the full period and 0.04 for the restricted period. This cumulative evidence suggests that the positive effect we estimate for the development project is unlikely due to chance even for this small sample ${ }^{42}$

This analysis has been implemented using a very small number of cases from a relatively small part of Congo, and we therefore do not pretend to make a general claim here for the relation between development aid and conflict. Our goal here is to illustrate the promise of a real-time system such as Voix des Kivus. Our analysis points, we think, to an important advantage of real time data for the assessment of causal effects. Existing studies of the effects of development interventions often produce contradictory results. Yet, these studies differ on many dimensions of design, including the temporal lag between intervention and measurement. An analysis using real-time data allows one to measure the extent to which

\footnotetext{
two months.

${ }^{40}$ Other approaches to deal with the multiple comparisons problem include using an index of measures (the approach adopted by Kling et al. (2007) for example), statistical adjustments, such as the Bonferroni or Šidák corrections (see also Benjamini and Hochberg (1995) for methods to control the false discovery rate), or multi-level approaches (Gelman et al. | 2009).

${ }^{41}$ Each regression is thus for the whole period under study.

${ }^{42}$ We highlight that this test assesses the sharp null of no effect for any unit. The effects we observe are consistent with a spillover effect in which conflict shifted from treated units to control units and we cannot rule out this possibility in the current analysis.
} 
the variance in estimated effects depends on the timing of measurement. For example, measures of conflict events that took place in the month prior to data collection might yield an estimated effect with low variance. However, while this within-period variance is low, the across-period variance might be high: very different estimates might have been produced if data were gathered a month earlier or a month later. The top left panel in Figure 3 suggests the timing of measurement contributes a large share of the true variance in estimates of treatment effects ${ }^{43}$ For example, a researcher collecting data in October 2010 (for that month and the preceding two months) would conclude that there is no impact of development aid $(\beta=-0.9$ and $p=0.74)$. On the other hand, if that same researcher had conducted her study three months earlier or three months later, she would have concluded that there is strong evidence in favor of development aid $(\beta=-8.7, p=0.02$ and $\beta=-8.8$, $p=0.07$, respectively).

\subsection{Application 2: Spatial Clustering and Diffusion of Conflict}

Conflict is often geographically clustered. One reason might be that geographically proximate units are similar to each other; another is that conflict might "spill over" from one location to the next. Population flows may be one driver for diffusion by facilitating the spread of arms, combatants, and ideologies conducive to conflict (Kuran, 1998), altering an area's ethnic composition (Buhaug, 2008), or exacerbating economic competition (Salehyan and Gleditsch, 2006, Van Acker, 2005, Claessens et al., 2013; Vlassenroot and Huggins, 2005; Autesserre, 2009, 2010), 44

While initially limited to research on international conflict (Starr and Most, 1983 , O'Loughlin, 1986), diffusion-based explanations have since permeated cross-national studies of civil war (Braithwaite, 2010; Buhaug, 2008). Disaggregated research on the local dynamics of conflict, however, is more sparse. One reason for this is the difficulty of obtaining high-quality, dynamic data on conflict at the micro-level. This is unfortunate because there is reason to believe that conflict diffusion can operate at a very micro level. For example, in Eastern Congo most population movements take place within chiefdoms, with migrants moving to nearby villages often only several kilometers away. In this second application we illustrate the usefulness of crowdseeding data to learn about conflict diffusion at this level. Moreover, we will also illustrate the usefulness of temporal fine grain by showing how data collected following a survey-based approach can bias conclusions about conflict diffusion.

\footnotetext{
${ }^{43}$ Analyzing both sources of variance directly we find that the variance in estimated effects depends strongly on the timing of measurement. Starting from month 4, the variance in estimates of the treatment effect over months 4-24 is 194; the average variance within each period however is just 12 . Things settle down after month 6 , but even still the variance in estimates over time (months $7-24$ ) is 12 while the average variance is 11 .

${ }^{44}$ Another channel found to be important is the negative impact of conflict on regional economic growth, which lowers the opportunity costs of rebellion in neighboring areas (Murdoch and Sandler, 2002).
} 
Diffusion has been an important force in the spread and duration of conflict in Congo's South Kivu province. The First Congo War (1996-7) and the Second Congo War (19982003) were plausibly a direct result of the 1994 Rwandan genocide, with an estimated influx of nearly 1.5 million Rwandans ${ }^{45}$ Internal migration rates are also high in the region. A survey conducted in 2007 in over 600 randomly-selected villages throughout Eastern Congo finds that a full $71 \%$ of individuals in South Kivu had fled at least once at some point during the period 1996-2007 due to armed activities by organized armed groups or militias ${ }^{46}$ Table 1 corroborates the presence of forced movements also for our Voix des Kivus villages (codes 53, 54, 56).

Does conflict diffuse in the South Kivu province? We investigate the question by analyzing whether conflict in a village in a given period is more likely if conflict was higher in the previous period in neighboring villages. To estimate the magnitude and scope of such spillover effects we pool our village-period data and model the diffusion process with a simple spatial autoregressive model:

$$
y_{i t}=\alpha+\rho \sum_{j \in N(i)} y_{j, t-1}+\beta y_{i, t-1}+\epsilon_{i t}
$$

where $\sum_{j \in N(i)} y_{j, t-1}$ is the spatial lag, which can be interpreted as a sum of the number of conflict events in villages in $i$ 's neighborhood, $N(i)$, in the preceding period ${ }^{47}$ The term $y_{i, t-1}$ is the lagged dependent variable for village $i$, and $\epsilon_{i t}$ is an error term-assumed to be independent and identically distributed ${ }^{48}$ Note that this equation does not include village fixed effects, though these are examined below 49

Equation 1 requires a choice about how a neighbor is defined. Are only villages less than ten kilometers away neighbors, or are villages 40 kilometers away also neighbors? This decision can exert a significant influence on the magnitude and scope of estimated diffusion effects Anselin, 2002, Zhukov and Stewart, 2012).

In South Kivu those individuals that migrate due to conflict often only move a few kilometers from their village of origin - moving to the nearest safe village or to those villages with family. In 2012 one of the authors collected information about the migration histories of 8,199 adults in the Buhavu chiefdom - one of two chiefdoms in South Kivu's territory of

\footnotetext{
${ }^{45}$ For historical roots, see Prunier (1997) and Prunier (2009).

${ }^{46}$ See: Humphreys (2008). Such conflict-induced migration has also been characteristic for the region in more recent years due to sustained rebel activity and military operations by the government such as the 2009 joint Congo-Rwanda military offensive Umoja Wetu against the FDLR, followed by Kimia II and Amani Leo.

${ }^{47}$ Note that including this summation term means the results are sensitive to the number of villages in the data set, and thus controlling for temporal fixed effects is important. This is not an issue in our analysis below because the number of villages is fixed for the period chosen for analysis.

${ }^{48}$ The interpretation is that there is the own-village lag effect and also the "neighbor" lag effect, and we are looking at the latter conditional on the former.

${ }^{49}$ Note that there are biases from estimating fixed effects with lagged dependent variables, which disappear when the number of time periods is large (Nickell, 1981)
} 
Kalehe. 50 The data show that $92 \%$ of all movements that originated in the Buhavu chiefdom and were caused by conflict - which totaled 4,431 movements - ended in a different village, but in the same chiefdom. Conflict-induced migration is thus very local in South Kivu, and we might expect that conflict diffusion is as well. As a result, to test whether conflict diffusion operates at such a fine-grained level, we estimate the spatial autoregressive model multiple times, each time with a different definition of neighbor. Specifically, Equation 1 is estimated with a neighbor consecutively defined as those villages inside the intervals 0 to $\{6-50\}$ kilometers.

We also test directly the benefit of a crowdseeding system to collect very precise data on the timing of conflict events. To do so we estimate Equation 1 twice: once where we do not leverage the temporal variation of the data, and once where we do. Specifically, to learn about conflict diffusion a researcher might conduct a survey twice in our Voix des Kivus villages collecting in each survey the number of conflict events that took place in the previous period. With both surveys taking place at different points of time, the conflict events recorded in the first survey would constitute the baseline levels on the outcome variable for the subsequent period $\left(y_{i, t-1}\right.$ in Equation 11) In contrast to such surveystyle data, which collects data for two periods only, a crowdseeded dataset is more finegrained with information about the exact timing of events. To leverage this information we undertake the same analysis but using the village-week as the unit of analysis ${ }^{52}$ We now compare the results based upon these different datasets.

The first two panels in Figure 4 present the results for each type of analysis. The black, solid line indicates the estimated impact of conflict in neighboring villages in the previous period on a village's incidence of conflict in this period, for a given definition of neighbor; the gray areas indicate the $95 \%$ confidence interval. Results are from one-tailed tests (Does conflict spill to the next village?).

The left panel presents results from estimating Equation 1 based on the "survey-style" data - that is data without the temporal fine grain, clustering the error at the village level. Two results stand out. First, conflict in neighboring villages in the previous period is associated with fewer conflict events in this period. Second, conflict diffusion appears to operate at the micro level. An additional conflict event in a village less than 25 kilometers away decreases the number of conflict events by 0.2 ; a result that is not only statistically, but also substantially significant. As we broaden the definition of neighbor, and thus include more villages, the estimated magnitudes decreases. Given these results, a researcher might conclude that migrant spillovers have a positive impact on neighboring villages.

\footnotetext{
${ }^{50}$ This area includes five of our Voix des Kivus villages: the upper five villages in Figure 1 The migration data can be found online: www.petervanderwindt.com/research

${ }^{51}$ Specifically, to simulate this setup in our data we group six months for which we have information from all villages (November-April, 2011) into two periods each consisting of those conflict events that took place over three months.

${ }^{52}$ Crowdseeded data can also be analyzed at a more fine-grained level such as by day or - if the data allows it-hour. We do not do so in this paper.
} 
Perhaps in anticipation of responses by peacekeepers or other armed groups, rebel groups shun an area after attacking a village during the previous period.
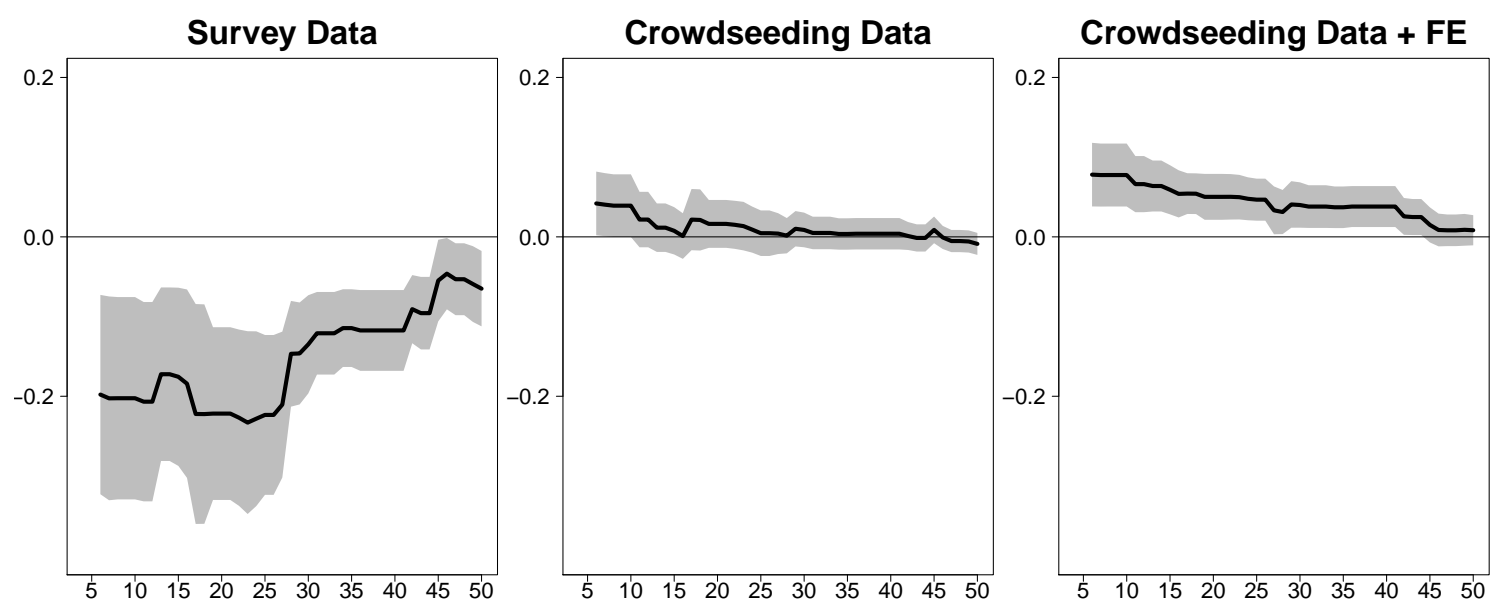

Figure 4: Conflict Diffusion in South Kivu: By Type of Data Collected. The two left panels show results from estimating Equation 1 on the survey-based data and the crowdseeded data, respectively, with errors clustered at the village level. The solid black lines indicate point estimates at one kilometer intervals. Gray areas indicate $95 \%$ confidence intervals. The right panel presents results from estimating Equation 1 on crowdseeded data but now also controlling for village-level fixed effects. For all three panels values at the $\mathrm{x}$-axis are the number of kilometers below which a village is defined as neighbor.

Results are very different, however, when the temporal variation provided by crowdseeded data is taken into account. The center panel presents results from estimating exactly the same model but on the more fine-grained data. We now find evidence for conflict diffusion: that is, the point estimates are consistently above the zero line. We again find that previous conflict in villages nearby have a larger impact than those villages further away. An additional conflict event in a village less than ten kilometers away increases the number of conflict events by 0.05 ; a result that is not only statistically, but also substantively, significant. The figure illustrates clearly how this impact decreases as we broaden the definition of neighbor, and quickly becomes non-significant. The point estimate for villages within 50 kilometers is zero.

A weakness of both of these analyses is that they fail to distinguish between true diffusion and common causes of conflict among neighbors. While we assumed $\epsilon_{i t}$ to be independent and identically distributed, variables such as the presence of a rebel group or a bad harvest might cluster and this might drive our results. Hegre et al. (2001), for example, find that the apparent clustering of civil war is fully explained by the clustering 
of domestic factors (mainly GDP per capita and regime type). We do not have information about such factors for our Voix des Kivus villages. However, a major benefit of data that has variation over time is that it allows the researcher to estimate Equation 1 controlling for village-level fixed effects. ${ }^{53}$ Results from doing so are reported in the right panel of Figure 4. We find that our point estimates almost double and that the confidence interval hits the zero bound only at 40 kilometers.

This application illustrates two points. First, it highlights the importance of getting the geographic level right. Conflict dynamics might operate at the very micro-level geographically (see also Schutte and Weidmann (2011)). Diffusion that can be observed at a very fine resolution may be invisible at a lower resolution. For this, crowdseeding data shares strengths with datasets such as ACLED that provide fine geographic detail (a.o. Raleigh et al. (2010), Hegre et al. (2009), Buhaug et al. (2011), Weidmann and Ward (2010)), though it benefits from a greater density of reported events. Second, the analysis illustrates the importance of temporal fine grain. It illustrated how conclusions based on temporally coarse data can produce conclusions diametrically opposed to what is found with more fine grained data. It is possible that effects work at different registers - a more sophisticated model than that provided in Equation 11 might find for example that in the short run there is local diffusion but in the longer run conflict moves farther afield. Assessing such dynamics, however, requires exactly the fine grain illustrated above.

\section{Conclusion}

The past decade has seen much effort to better understand the causes and consequences of violent conflict. Much of the empirical analysis, however, makes use of data at high levels of aggregation (often the country and year level). It is therefore not surprising that in their survey of the civil war literature Blattman and Miguel (2010) argue that "a major goal of civil war researchers within both economics and political science in the coming years should be the collection of new data, especially extended panel micro-data sets..." Original micro-level data is normally collected by conducting surveys or interviews. The collection of conflict data in particular faces a set of challenges because of the nature of the areas in which conflict events take place. These events take place in insecure areas and are therefore often off-limits to researchers; and if data is gathered long after the fact, it may suffer from various forms of recall and selection bias.

In this paper we investigated whether a SMS-based "crowdseeding" system can be used to obtain high-quality, micro-level panel data on conflict. To address the question we piloted the Voix des Kivus system between 2009 and 2011 in the war-torn South Kivu province of the Democratic Republic of Congo. Reporters were selected from randomly

\footnotetext{
${ }^{53}$ Fixed effects in the presence of a lagged dependent variable runs a risk of bias, especially for short panels (Arellano and Bond (1991)). An advantage of real time data however is that panels can quickly become longer than wide.
} 
sampled areas, provided cell phones and credit, and invited to provide regular reports to the system. This approach holds out the promise of multiple benefits for data quality, which includes a claim to representativeness and the possibility of collecting conflict event data in real-time. By implementing such a crowdseeding system we hope to overcome the problems that come with current methods to collect data on conflict.

A first objective in this research was to probe the feasibility of employing a crowdseeding approach to gathering high-quality data on conflict events in real-time. We found that users had the capacity and willingness to engage at high levels, the technical implementation both at the village level and the processing level were smooth. Also the costs required to collect data - especially compared to more traditional approaches - were relatively modest.

A second goal was to illustrate the use and benefits of crowdseeding data. In a first application, we took advantage of exogenous variation resulting from the random implementation of a development project to assess whether aid is associated with increased or reduced levels of violence. We implemented Voix des Kivus in such a way that some Voix des Kivus villages received the development project, and others not. Despite the small sample, we find evidence for a negative relationship between aid and conflict. In a second application we exploit the fine grain of the data to examine conflict diffusion patterns. We find evidence that conflict events shift from site to site but find that evidence for diffusion disappears at a resolution of about $50 \mathrm{~km}$. Critically, by exploiting the continuous nature of our data, both applications highlight the sensitivity of estimates to the timing of measurement in a way that cannot be assessed from traditional cross-sectional data.

Ultimately, however, the value of the system depends on the quality of the data that it generates. Our initial probes, using validation by our agent in the field, through comparison of reports across reporters, and through comparison with survey data, suggest that the data is capturing major trends faithfully. However, the data differs both qualitatively and quantitatively from that from other sources. Comparisons with ACLED data for example suggest a greater volume of events and a higher attribution of conflict events to Congolese government troops. Moreover, high correlations in the reporting of different types of events as well as large variation in the number of events reported by different areas suggest that accuracy may be affected by uneven reporter engagement with the system. Given the promise of the system we believe that there is need now for more formal validation of data from crowdseeding, perhaps in conjunction with a validation of crowdsourced data, that would seek to assess rates of Type I and Type II errors relative to data systematically collected through intensive application of traditional methods.

We close with reflections on the ethical implications of taking a project like this to scale. During the pilot project we faced no incidents that threatened the safety of the reporters. However, things might be different if a project of this form were scaled up and attracted the interest of armed groups. For both humanitarian and research purposes a project such as Voix des Kivus becomes truly useful only when it is taken to scale; but those are precisely the conditions which might create the greatest risks. We did not assess these risks because we could not bear them ourselves. But given the importance and utility 
of the data these are risks that local and international groups operating in these regions might be prepared to bear. 


\section{References}

Anderson, M. B. (1999). Do No Harm: How Aid Can Support Peace - or War. Lynne Rienner, London.

Anselin, L. (2002). Under the Hood: Issues in the Specification and Interpretation of Spatial Regression Models. Agricultural Economics, 27(3):247-267.

Arellano, M. and Bond, S. (1991). Some Tests of Specification for Panel Data: Monte Carlo Evidence and an Employment Equations. Review of Economic Studies, 58(2):277-297.

Autesserre, S. (2009). Hobbes and the Congo: Frames, Local Violence, and International Intervention. International Organization, 63(2):249-280.

Autesserre, S. (2010). The Trouble with the Congo. Local Violence and the Failure of International Peacebuilding. Cambridge University Press, New York City.

Barrios, T., Diamond, R., Imbens, G. W., and Kolesár, M. (2012). Clustering, Spatial Correlations and Randomization Inference. Journal of the American Statistical Association, 107(498):578-591.

Bates, R. H. (2009). Prosperity \& Violence: The Political Economy of Development. W. W. Norton \& Company, New York City, 2nd edition.

Beath, A., Christia, F., and Enikolopov, R. (2011). Winning Hearts and Minds through Development Aid: Evidence from a Field Experiment in Afghanistan. Working paper.

Benjamini, Y. and Hochberg, Y. (1995). Controlling the False Discovery Rate: A Practical and Powerful Approach to Multiple Testing. Journal of the Royal Statistical Society. Series B (Methodological), 57(1):289-300.

Berinsky, A. J., Huber, G. A., and Lenz, G. S. (2012). Evaluating Online Labor Markets for Experimental Research: Amazon.com's Mechanical Turk. Political Analysis, 20(3):351368.

Berman, E., Shapiro, J. N., and Felter, J. H. (2011). Can Hearts and Minds Be Bought? The Economics of Counterinsurgency in Iraq. Journal of Political Economy, 119(4):766819.

Blattman, C. and Miguel, E. (2010). Civil War. Journal of Economic Literature, 48(1):357.

Braithwaite, A. (2010). Resisting Infection: How State Capacity Conditions Conflict Contagion. Journal of Peace Research, 47(3):311-319. 
Buhaug, H. (2008). Contagion or Confusion? Why Conflicts Cluster in Space. International Studies Quarterly, 52(2):215-233.

Buhaug, H., Gleditsch, K. S., Holtermann, H., Ostby, G., and Tollefsen, A. F. (2011). It's the Local Economy, Stupid! Geographic Wealth Dispersion and Conflict Outbreak Location. Journal of Conflict Resolution, 55(5):814-840.

Claessens, K., Mudinga, E., and Ansoms, A. (2013). Land Grabbing by Local Elites in the Territory of Kalehe, South Kivu, Eastern DRC. Working paper.

Cohen, N. and Arieli, T. (2011). Field Research in Conflict Environments: Methodological Challenges and Snowball Sampling. Journal of Peace Research, 48(4):423-435.

Collier, P. (2003). Breaking the Conflict Trap: Civil War and Development Policy. Oxford University Press, New York City.

Corstange, D. (2008). Sensitive Questions, Truthful Answers? Modeling the List Experiment with LISTIT. Political Analysis, 17(1):45-63.

Coughlin, S. S. (1990). Recall Bias in Epidemiologic Studies. Journal of Clinical Epidemiology, 43(1):87-91.

Crost, B., Felter, J. H., and Johnston, P. (2012). Aid Under Fire: Development Projects and Civil Conflict. Working paper.

De Nicola, F. and Giné, X. (2014). How Accurate Are Recall Data? Evidence from Coastal India. Journal of Development Economics, 106:52-65.

De Ree, J. and Nillesen, E. (2009). Aiding Violence or Peace? The Impact of Foreign Aid on the Risk of Civil Conflict in Sub-Saharan Africa. Journal of Development Economics, 88(2):301-313.

De Waal, A. (2009). Famine Crimes: Politics \& the Disaster Relief Industry in Africa. Indiana University Press, Bloomington.

Fearon, J. D. and Laitin, D. D. (2003). Ethnicity, Insurgency, and Civil War. American Political Science Review, 97(1):75-90.

Fisher, R. A. (1935). The Design of Experiments. Oliver and Boyd, London.

Gelman, A., Hill, J., and Yajima, M. (2009). Why We (Usually) Dont Have to Worry About Multiple Comparisons. Working paper.

Hegre, H., Ellingsen, T., Gates, S., and Gleditsch, N. P. (2001). Toward a Democratic Civil Peace? Democracy, Political Change, and Civil War, 1816-1992. American Political Science Review, 95(1):33-48. 
Hegre, H., Ostby, G., and Raleigh, C. (2009). Poverty and Civil War Events: A Disaggregated Study of Liberia Poverty and Civil War Events. Journal of Conflict Resolution, 53(4):598-623.

Henderson, J. V., Storeygard, A., and Weil, D. N. (2012). Measuring Economic Growth from Outer Space. American Economic Review, 102(2):994-1028.

Henderson, V., Storeygard, A., and Weil, D. N. (2011). A Bright Idea for Measuring Economic Growth. American Economic Review, 101(3):194-199.

Ho, D. E. and Imai, K. (2006). Randomization Inference With Natural Experiments: An Analysis of Ballot Effects in the 2003 California Recall Elections. Journal of the American Statistical Association, 101(475):888-900.

Humphreys, M. (2008). Community-Driven Reconstruction in the Democratic Republic of Congo: Baseline Report. Technical report.

Imai, K., King, G., and Stuart, E. A. (2008). Misunderstandings Between Experimentalists and Observationalists About Causal Inference. Journal of the Royal Statistical Society: Series A, 171(2):481-502.

Kling, J. R., Liebman, J. B., and Katz, L. F. (2007). Experimental Analysis of Neighborhood Effects. Econometrica, 75(1):83-119.

Kuran, T. (1998). Ethnic Dissimilation and Its International Diffusion. In Lake, D. A. and Rotchild, D., editors, The International Spread of Ethnic Conflict: Fear, Diffusion, and Escalation, pages 35-60. Princeton University Press, Princeton.

Lujala, P. (2010). The Spoils of Nature: Armed Civil Conflict and Rebel Access to Natural Resources. Journal Of Peace Research, 47(1):15-28.

Lujala, P., Gleditsch, N. P., and Gilmore, E. (2005). A Diamond Curse? Civil War and a Lootable Resource. The Journal of Conflict Resolution, 49(4):538-562.

Luyendijk, J. (2009). People Like Us: Misrepresenting the Middle East. Soft Skull Press, New York City.

Miguel, E., Satyanath, S., and Sergenti, E. (2004). Economic Shocks and Civil Conflict: An Instrumental Variables Approach. Journal of Political Economy, 112(4):725-753.

Murdoch, J. C. and Sandler, T. (2002). Economic Growth, Civil Wars, and Spatial Spillovers. Journal of Conflict Resolution, 46(1):91-110.

Mutz, D. and Pemantle, R. (2011). The Perils of Randomization Checks in the Analysis of Experiments. Working paper. 
Nickell, S. (1981). Biases in Dynamic Models with Fixed Effects. Econometrica, 49(6):14171426.

Nunn, N. and Qian, N. (2014). US Food Aid and Civil Conflict. American Economic Review, 104(6):1630-1666.

O'Loughlin, J. (1986). Spatial Models of International Conflicts: Extending Current Theories of War Behavior. Annals of the Association of American Geographers, 76(1):63-80.

Polman, L. (2011). The Crisis Caravan: What's Wrong with Humanitarian Aid? Picador, New York City.

Prunier, G. (1997). The Rwanda Crisis: History of a Genocide. Columbia University Press, New York City.

Prunier, G. (2009). Africa's World War: Congo, the Rwandan Genocide, and the Making of a Continental Catastrophe. Oxford University Press, Oxford.

Raleigh, C. and Hegre, H. (2009). Population Size, Concentration, and Civil War. A Geographically Disaggregated Analysis. Political Geography, 28(4):224-238.

Raleigh, C., Linke, A., Hegre, H., and Karlsen, J. (2010). Introducing ACLED: An Armed Conflict Location and Event Dataset. Journal of Peace Research, 47(5):651-660.

Salehyan, I. and Gleditsch, K. S. (2006). Refugees and the Spread of Civil War. International Organization, 60(02):335-366.

Schutte, S. and Weidmann, N. B. (2011). Diffusion Patterns of Violence in Civil Wars. Political Geography, 30(3):143-152.

Small, D. S., Ten Have, T. R., and Rosenbaum, P. R. (2008). Randomization Inference in a Group-Randomized Trial of Treatments for Depression. Journal of the American Statistical Association, 103(481):271-279.

Starr, H. and Most, B. A. (1983). Contagion and Border Effects on Contemporary African Conflict. Comparative Political Studies, 16(1):92-117.

Van Acker, F. (2005). Where Did All the Land Go? Enclosure and Social Struggle in Kivu (D.R.Congo). Review of African Political Economy, 32(103):79-98.

Van der Windt, P. (2013). From Crowdsourcing to Crowdseeding: The Cutting Edge of Empowerment? In Livingston, S. and Walter-Drop, G., editors, Bits and Atoms: Information and Communication Technology in Areas of Limited Statehood, chapter 10, pages 144-156. Oxford University Press, New York City. 
Verwimp, P., Justino, P., and Bruck, T. (2009). The Analysis of Conflict: A Micro-Level Perspective. Journal of Peace Research, 46(3):307-314.

Vlassenroot, K. and Huggins, C. (2005). Land, Migration and Conflict in Eastern DRC. From the Ground Up: Land Rights, Conflict and Peace in Sub-Saharan Africa, pages 115-194.

Weidmann, N. B., Rod, J. K., and Cederman, L.-E. (2010). Representing Ethnic Groups in Space: A New Dataset. Journal of Peace Research, 47(4):491-499.

Weidmann, N. B. and Ward, M. D. (2010). Predicting Conflict in Space and Time. Journal of Conflict Resolution, 54(6):883-901.

Zeitzoff, T. (2011). Using Social Media to Measure Conflict Dynamics: An Application to the 2008-2009 Gaza Conflict. Journal of Conflict Resolution, 55(6):938-969.

Zhukov, Y. M. and Stewart, B. M. (2012). Choosing Your Neighbors: Networks of Diffusion in International Relations. International Studies Quarterly, 527(2):271-287. 
Online Appendix: Messages by Reporter Position

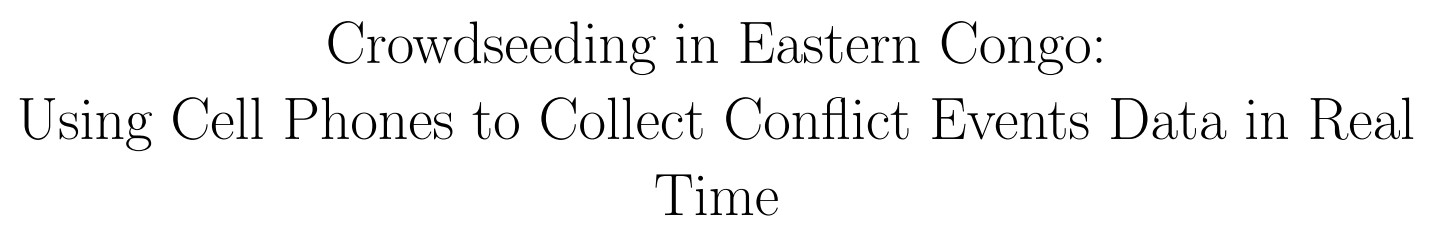

Peter van der Windt Macartan Humphreys

August 14, 2014 


\begin{tabular}{|c|c|c|c|c|c|c|c|}
\hline Code & Event & Chief & Woman & Elec. & $\Delta(\mathrm{C}-\mathrm{W})$ & $\Delta(\mathrm{C}-\mathrm{E})$ & $\Delta(\mathrm{W}-\mathrm{E})$ \\
\hline 10 & PRESENCE OF MILITARY FORCES & 0.02 & 0.02 & 0.02 & 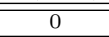 & 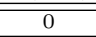 & 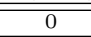 \\
\hline 11 & Presence of MONUSCO & 1.04 & 0.41 & 0.10 & 0.63 & 0.93 & 0.3 \\
\hline 12 & Presence of FARDC & 0.93 & 0.74 & 0.37 & 0.18 & 0.56 & 0.38 \\
\hline 13 & Presence of other armed groups & 0.10 & 0.02 & 0.09 & 0.08 & 0.01 & $-0.07 *$ \\
\hline 20 & ATTACKS (use of violence by an external group) & 0.01 & 0.01 & 0.01 & 0.01 & 0.01 & 0 \\
\hline 21 & Attacks on village by MONUSCO & 0.01 & 0.03 & 0.01 & -0.03 & 0 & 0.03 \\
\hline 22 & Attacks on village by FARDC & 0.09 & 0.06 & 0.17 & 0.03 & -0.07 & -0.11 \\
\hline 23 & Attacks on village by rebel group & 0.08 & 0.11 & 0.05 & -0.04 & 0.03 & $0.06^{*}$ \\
\hline 24 & Attacks on the village by unknown group & 0.02 & 0.04 & 0.05 & -0.02 & -0.03 & -0.01 \\
\hline 30 & DEATHS RELATED TO ARMED COMBAT & 0.06 & 0.01 & 0.03 & 0.06 & 0.03 & -0.02 \\
\hline 31 & Civilian deaths (man) & 0.27 & 0.13 & 0.13 & 0.15 & 0.14 & 0 \\
\hline 32 & Civilian deaths (woman) & 0.27 & 0.11 & 0.14 & 0.16 & 0.13 & -0.03 \\
\hline 33 & Civilian deaths (child) & 0.15 & 0.05 & 0.09 & 0.1 & 0.06 & -0.04 \\
\hline 34 & MONUSCO deaths & 0.01 & 0.01 & 0.01 & 0 & 0.01 & 0.01 \\
\hline 35 & FARDC deaths & 0.10 & 0.05 & 0.06 & 0.05 & 0.04 & -0.02 \\
\hline 36 & Other rebel group deaths & 0.01 & 0.01 & 0.01 & 0.01 & 0 & -0.01 \\
\hline 40 & LOCAL VIOLENCE AND PROPERTY LOSS & 0.01 & 0.01 & 0.03 & 0 & -0.02 & -0.02 \\
\hline 41 & Rioting & 0.15 & 0.09 & 0.18 & 0.06 & -0.03 & -0.09 \\
\hline 42 & Looting/property damage & 0.34 & 0.39 & 0.64 & -0.05 & -0.3 & -0.25 \\
\hline 43 & Violence between villagers & 0.14 & 0.03 & 0.06 & $0.12^{*}$ & 0.09 & -0.03 \\
\hline 44 & Violence between villagers due to a land conflict & 0.10 & 0.03 & 0.59 & $0.07 *$ & -0.49 & -0.56 \\
\hline 45 & Domestic violence & 0.05 & 0.03 & 0.05 & 0.02 & 0 & -0.02 \\
\hline 46 & Ethnic violence & 0.00 & 0.01 & 0.02 & -0.01 & -0.02 & -0.01 \\
\hline 47 & Forced labor by FARDC & 0.12 & 0.16 & 0.06 & -0.04 & 0.06 & 0.1 \\
\hline 48 & Forced labor by other army groups & 0.02 & 0.06 & 0.02 & -0.04 & 0 & 0.04 \\
\hline 50 & DISPLACEMENT & 0.00 & 0.01 & 0.00 & -0.01 & 0 & 0.01 \\
\hline 51 & Kidnapping by men in uniform & 0.20 & 0.19 & 0.13 & 0.01 & $0.07^{*}$ & 0.06 \\
\hline 52 & Kidnapping by rebel group & 0.14 & 0.05 & 0.06 & 0.1 & 0.09 & -0.01 \\
\hline 53 & Arrival of Refugees or IDPs & 0.07 & 0.11 & 0.01 & -0.04 & $0.05^{* *}$ & 0.1 \\
\hline 54 & Departure of villagers as IDPs & 0.11 & 0.09 & 0.01 & 0.03 & 0.1 & 0.07 \\
\hline 55 & Disappearances & 0.03 & 0.00 & 0.01 & $0.03 *$ & 0.02 & -0.01 \\
\hline 56 & Villagers were forced to move & 0.03 & 0.02 & 0.01 & 0.02 & 0.03 & 0.01 \\
\hline 57 & Villagers decided themselves to move & 0.02 & 0.00 & 0.00 & 0.02 & 0.02 & 0 \\
\hline 60 & HEALTH & 0.03 & 0.03 & 0.04 & 0 & -0.01 & -0.01 \\
\hline 61 & New outbreak of disease & 0.63 & 0.58 & 0.40 & 0.05 & 0.23 & 0.18 \\
\hline 62 & Civilian death due to disease & 0.82 & 0.95 & 0.90 & -0.13 & -0.08 & 0.05 \\
\hline 63 & Civilian death due to natural causes & 0.08 & 0.15 & 0.19 & -0.06 & -0.11 & -0.04 \\
\hline 64 & Sexual violence against women & 0.08 & 0.08 & 0.13 & 0 & -0.05 & -0.05 \\
\hline 65 & Sexual violence against men & 0.01 & 0.01 & 0.28 & 0.01 & -0.27 & -0.28 \\
\hline 70 & NATURAL DISASTERS & 0.07 & 0.05 & 0.07 & 0.03 & 0 & -0.02 \\
\hline 71 & Flooding/heavy rain & 0.35 & 0.14 & 0.23 & $0.21^{*}$ & 0.12 & -0.09 \\
\hline 72 & Large forest or village fire & 0.18 & 0.22 & 0.26 & -0.04 & -0.07 & -0.03 \\
\hline 73 & Earthquake & 0.11 & 0.05 & 0.07 & 0.07 & 0.04 & -0.02 \\
\hline 74 & Drought & 0.07 & 0.08 & 0.06 & -0.01 & 0 & 0.02 \\
\hline 75 & Crop failure/plague & 0.70 & 0.63 & 0.81 & 0.07 & -0.12 & -0.18 \\
\hline 80 & DEVELOPMENT ACTIVITIES/ NGOS & 0.34 & 0.13 & 0.37 & $0.21^{*}$ & -0.03 & -0.24 \\
\hline 81 & Complaint against NGO & 0.09 & 0.08 & 0.07 & 0.01 & 0.02 & 0.01 \\
\hline 85 & Construction, reparation or rehabilitation of a school or health center & 0.07 & 0.02 & 0.03 & $0.05 *$ & 0.04 & -0.02 \\
\hline 86 & Construction, reparation or rehabilitation of a church or mosque & 0.07 & 0.04 & 0.01 & 0.03 & $0.05 *$ & 0.03 \\
\hline 87 & Other construction, reparation or rehabilitation & 0.39 & 0.14 & 0.06 & 0.26 & 0.33 & $0.08^{* *}$ \\
\hline 88 & Organization of security patrols & 0.04 & 0.04 & 0.02 & 0 & 0.02 & 0.02 \\
\hline 89 & Work to improve agricultural productivity & 0.20 & 0.11 & 0.05 & 0.09 & $0.15^{*}$ & 0.06 \\
\hline 90 & SOCIAL & 0.04 & 0.01 & 0.03 & 0.03 & 0.01 & -0.02 \\
\hline 91 & Funeral & 0.28 & 0.26 & 0.17 & 0.02 & 0.11 & 0.09 \\
\hline 92 & Wedding/Other celebrations & 0.25 & 0.19 & 0.11 & 0.07 & $0.14^{* *}$ & 0.08 \\
\hline 93 & Visit or meeting organized by national or provincial authorities & 0.08 & 0.02 & 0.05 & 0.05 & 0.03 & -0.02 \\
\hline 94 & Visit or meeting organized by territoire authorities & 0.01 & 0.02 & 0.02 & -0.01 & -0.01 & 0 \\
\hline 95 & Visit or or meeting organized by the chefferie or locality authorities & 0.09 & 0.09 & 0.02 & 0 & $0.07^{* *}$ & $0.07 *$ \\
\hline 96 & Visit or meeting organized by the representative of a political party & 0.17 & 0.09 & 0.05 & 0.09 & $0.12 *$ & 0.03 \\
\hline 97 & Visit or meeting organized by the King & 0.12 & 0.03 & 0.05 & 0.09 & 0.08 & -0.01 \\
\hline 0 & Nothing to report & 0.34 & 0.34 & 0.44 & 0 & -0.1 & -0.1 \\
\hline 82 & Practice message & 0.17 & 0.09 & 0.22 & 0.08 & -0.05 & -0.13 \\
\hline 98 & Unclassifiable issue (followed by text) & 0.99 & 0.45 & 0.49 & $0.54^{* *}$ & 0.49 & -0.05 \\
\hline \multirow[t]{2}{*}{99} & Security Alert & 0.14 & 0.20 & 0.13 & -0.06 & 0.01 & 0.07 \\
\hline & Total & 11.71 & 8.34 & 9.05 & 3.37 & 2.66 & -0.71 \\
\hline
\end{tabular}

Table 1: Voix des Kivus Messages by Reporter Position. Based on a total of 529 reporter position-months. For reasons of space standard errors are omitted, but significances are indicated by asterisks: one, two or three asterisks indicate, respectively, significance levels at the $90 \%, 95 \%$ and $99 \%$. For the comparison tests we cluster the errors at the village level. 